\title{
Ortaöğretim Okullarında Uygulanan Program Dışı Etkinliklerin Öğretmen Görüsslerine Göre Değerlendirilmesi
}

\author{
DOI: 10.26466/opus.709149
}

\author{
Ali Kocayiğit - Necla Ekinci** \\ * Öğretmen, MEB, Burdur/Türkiye \\ E-Posta: alikocayigit@hotmail.com \\ ORCID: $0000-0003-0110-9422$ \\ ** Doç. Dr., Muğla Sıtkı Koçman Üniversitesi, Eğitim Fakültesi, Muğla /Türkiye \\ E-Posta: alikocayigit@hotmail.com \\ ORCID: $\underline{0000-0001-9953-5862}$
}

\section{Öz}

Program dışı etkinlikler yoluyla edinilen deneyimler eğitim sürecinin önemli bir bileşenidir. Bu nedenle, eğitimcilerin olumlu bir sını ortamı oluşturmak için sadece sımı içi değişkenleri değil, aynı zamanda gün boyunca öğrenciyi etkileyen diğer değ̌işkenleri de göz önünde bulundurmaları gerekir. Bu araştırmanın amacı, ortaöğretim okullarında uygulanmakta olan program dışı etkinlikleri öğretmen görüşlerine göre değerlendirmektir. Bu araştırmada nitel araştırma modellerinden durum çalışması deseni kullanılmıştır. Araştırma, 2019-2020 Güz yarıyllında Burdur ilinde bulunan bir ilçede farklı lise türlerinde görev yapan on iki öğretmen ile gerçekleştirilmiştir. Çalışma grubu oluşturulurken, maksimum çeşitlilik ve ölçüt örnekleme yöntemlerinden yararlanılmıştır. Araştırmanın verileri araştırmacılar tarafindan geliştirilen yarı yapılandırılmış görüşme formu kullanılarak toplanmıştır. Elde edilen veriler, nitel veri analizi tekniklerinden içerik analizi ile kodlanmış, kodlardan kategorilere ve temalara ulaşılmıştır. Araştırmada ulaşılan temel sonuçlardan bazıları şöyledir: (a) Okullarda yürütülen program dışı etkinlikler sayı ve tür bakımından oldukça sınırlıdır, (b) Öğretmenler her ne kadar bazı zorluklarla karşılaşsalar da, program dişı etkinlikleri önemli görmektedirler ve (c) Bu tür etkinlikler öğrencilerin çok yönlü gelişimine olumlu katkı sağlamaktadır.

Anahtar Kelimeler: Program dışı etkinlikler, ortaöğretim, öğretmen görüşleri 


\title{
Evalution of Extracurricular Activities Implemented in High Schools According to Teachers' Opinions
}

\begin{abstract}
Experiences acquired through extracurricular activities are an important component of the educational process. Therefore, educators need to consider not only classroom variables but also other variables out of classroom affecting students throughout all day to create a positive learning environment.The purpose of this study is to evaluate the extra-curricular activities implemented in schools by teacher opinions. In the study, case study design, which is one of the qualitative research models, was employed. The study was carried out with twelve teachers working in different high schools in a district in Burdur province in fall term of 2019-2020 academic year. The study group was specified through the criterion and maximum variation sampling techniques. The data were collected by using semi-structured interview forms developed by the researchers. The data were coded with content analysis, one of the qualitative data analysis techniques, and categories and themes were reached from the codes. Some of the major results of the sduy are as follows: (a) The number and variety of the extra-curricalar activites implemented in schools are quite limited, (b) Teachers atribute high importance to extra-curricular activites, although they face some difficulties and (c) extra-curricular activites contribute into the versatile development of the students.
\end{abstract}

Keywords: Extra-curricular activities, secondary education, teacher views 


\section{Giriş}

Günümüzde okullardan beklenen temel sorumluluk, öğrencilere çağın gerektirdiği akademik beceriler yanında, sosyal ve kültürel değerleri de kazandırmasıdır. Bu beceri ve değerlerin okullarda ders içi ve ders dışı etkinliklerle bütüncül bir şekilde gerçekleştirilmesi bireylerin çok yönlü geliştirilmesi bakımından önemlidir.

Program dışı etkinlikler yoluyla edinilen deneyimler eğitim sürecinin önemli bir bileşenidir (Reeves, 2008; Seow ve Pan, 2014). Bu nedenle, eğitimcilerin olumlu bir sınıf ortamı oluşturmak için sadece sınıf içi değişkenleri değil, aynı zamanda gün boyunca öğrenciyi etkileyen diğer değişkenleri de göz önünde bulundurmaları gerekir. Program dışı etkinlikler bu bağlamda değerlendirilmesi gereken değişkenlerden birisidir.

Öğrencilerin okulda geçirdikleri çeşitli yaşantılar okul yaşamını olduğu gibi onların okul sonrası yaşamların da önemli ölçüde etkiler. Okul yaşamı öğrenenlerin, etkisi yaşam boyu sürecek olan bilişsel, duyuşsal, fiziksel ve sosyal yaşantılar sağlayan çeşitli eğitsel fırsatları deneyimledikleri zamanı ifade eder (Hill, 2010). Okullarda öğrenme süreci büyük ölçüde sınıflarda gerçekleşmektedir ancak pek çok öğrenci geleneksel sınıf ortamının dışındaki öğrenme etkinliklerinin de arayışı içindedir (Haensly, Lupkowski ve Edlind, 1985). Bu bağlamda Milli Eğitim Bakanlığı (MEB) Eğitim Kurumları Sosyal Etkinlikler Yönetmeliği'nin (MEB, 2017) ders dışı etkinliklere önemli vurgu yaptığı görülmektedir. Ders dışı etkinliklere yapılan bu vurgu, MEB'in okullardaki eğitim sürecinin sınıf içi ve dışı etkinliklere dayalı olarak yürütülmesi yönünde bir bakış açısına da vurgu olarak değerlendirilebilir. Yönetmelikte eğitim kurumlarında öğrencilerde özgüven ve sorumluluk duygusu geliştirmek, öğrencileri şiddet ve zararlı alışkanlıklardan korumak, öğrencilere yeni ilgi alanları ve beceriler kazandırmak, öğrencilerin yeteneklerini sergilemesine imkân vermek, millî, manevî ve kültürel değerleri yaşatmak, yaygınlaştırmak ve bu değerlerin yeni nesillere aktarımını sağlamak, öğrencilerde gönüllülük bilincini özendirmek, engellilik, yaşlılık, insan ve çocuk hakları konularında farkındalık oluşturmak amacıyla bilimsel, sosyal, kültürel, sanatsal ve sportif alanlarda sosyal etkinlik çalışmalarının yapılması gerektiği belirtilmektedir. Burada öğrencilere kazandırılması öngörülen niteliklerin ders ya da sınıf dışı etkinlikler aracılığı ile kazandırılmasının amaçlandığı görülmek- 
tedir. Öğrencileri her yönüyle geliştirme amaçlı görünen ders dişı bu tür etkinlikler alanyazında program dışı etkinlikler kapsamında ele alınmaktadır. Bartkus, Nemelka, Nemelka ve Gardner (2012) program dişı etkinleri “okul ortamında, normal sınıf/ders zamanının dışında, resmi programın bir parçası olmadan gerçekleşen, okulun gözetiminde, akademik ya da akademik olmayan, herhangi bir notla değerlendirmenin yapılmadığ nin isteğine bağlı olduğu etkinlikler" şeklinde tanımlamışlardır. Posner (1992) ise, program dışı etkinlikleri, sınıf içi ders konuları dışında planlanmış yaşantılardan oluşan bir süreç olarak tanımlamaktadır.

Öğrencilerin ders veya sınıf dışında gerçekleştirilen ders dışı etkinlikler yoluyla da bazı öğrenmeler gerçekleştirmesi söz konusudur. Ders dışında gerçekleşen öğrenmeler doğrudan resmi programın kazanımlarını gerçekleştirmeye dönük olabileceği gibi başka amaçlara da dönük olabilir (Ekinci, 2019). Program dışı etkinlikler öğrencilerin akademik başarılarına, özgüven gelişimlerine, sorumluluk bilincinin oluşmasına, sosyalleşmelerine, düşünme, iletişim, problem çözme ve karar verme gibi birçok davranış ve becerilerinin gelişimine olumlu yönde katkı sunar. Program dışı etkinlikler yalnızca öğrencinin okul performansını destekleyen, tamamlayan ve geliştiren etkinlikler değildir, aynı zamanda kişisel gelişimi, boş zaman, sağlık, değerler vb. yönleri de destekleyici etkinliklerdir (Moriana, Alós, Alcalá, Pino, Herruzo ve Ruiz, 2006). Köse (2013), çocuğun gelişiminde ders dışı etkinliklerin ders içi etkinlikler kadar önemli olduğunu ve bu tür etkinliklerle öğrencilerin formal öğretim süreci içerisinde öğrendiklerini pekiştirdiğini, bu öğrenmelerin yaşamla ilişkili olduğunu gösteren ve kuramsal öğrenmelerin uygulamaya konulmasını sağlayan etkinlikler olduğunu belirtmektedir. Ayrıca, ders dışı etkinliklerin formal öğretim etkinliklerinden ayrı veya bağımsız düşünmenin olanaksız olduğunu, burada en önemli koşulun ders dişı etkinliklerin kontrollü, programlı ve planlı bir şekilde yapılması olduğunu vurgulamıştır. Demir (2019) gelişmiş ülkelerin özellikle eğitimde program dışı etkinliklere sıklıkla yer verdiğini, PISA çalışmalarının sonuçlarına bakıldığında eğitimde program dışı etkinliklere daha çok yer veren Finlandiya'nın okulların yaşam kalitesini zevkli hale getiren etkinlikler düzenlediğini, uygulamalarda öğrencilerin ödev yapabilmesinin yanında farklı program dışı etkinliklere de yönelebildiklerini, bunun da akademik başarıyı beraberinde getirdiğini belirtmektedir. Bunların yanında, program dişı etkinlikler sosyo ekonomik düzeyi düşük ailelerden gelen çocukların üst sosyo-ekonomik ailelerin 
çocuklarının katıldığı etkinliklere (dans, müzik, sanat, spor vb.) katılım fırsatı vermekte ve dolayısıyla dezavantajlı grupların ilgi ve gereksinimlerine dönük etkinlikler sunulması mümkün olmaktadır. Farklı akran grupları (yetenek, gelir, başarı grupları) arasında etkileşime izin vermektedir. Öğrencilerin işbirliği becerilerini artırmaktadır. Etkinlikler düzenli ve yapılandırılmış etkinlikler olduğunda katılımcıların daha karmaşık beceriler geliştirmelerine katkı sağlayarak problem çözme ve baş etme becerilerini desteklemektedir. Niteliği yüksek, iyi yapılandırılmış program dışı etkinlilerin öğrenciler ile bu tür etkinliklere rehberlik eden öğretmenler arasındaki etkileşimi güçlendirmesi gibi kazanımlarından da söz edilmektedir (Holloway 2002). Haensly vd. (1985), çocukların yetişkinlerle etkileşiminin, yetişkin davranışları edinmelerine ve kişilik gelişimlerine yardımc olduğunu belirtmektedir. Böyle bir etkileşimde öğretmenin iletişime açı, yenilikçi ve rehberlik becerilerinin yüksek olması öğrenci ve öğretmen iletişimini güçlendirmektedir. Hill (2010), öğretmenlerin rol model olarak iletişim içinde olmalarının ve aynı yaş grubu akranların program dışı etkinliklere katılarak edindikleri deneyimlerin oldukça önemli ve değerli olduğunu belirtmektedir. Mahoney ve Cairns (1997) program dişı etkinlik çeşitliliğinin olduğu durumlarda, öğrencilerin bireysel ilgi ve gereksinimlerine daha fazla hitap edildiği için program dışı etkinliklere yönelimin arttı̆̆ını belirtmektedir. Bütün bu olumlu etkiler dikkate alındığında, program dışı etkinliklerin öğrencilerin okula, öğrenmeye ve çevrelerine karşı olumlu tutum geliştirmelerine katkısının olacağı anlaşılmaktadır.

Alanyazında konuyla ilgili; ortaokul öğretmenlerinin toplum hizmeti çalışmalarına ilişkin görüşleri (Gömleksiz ve Kılınç, 2015), ortaöğretim kurumlarındaki yöneticiler ve lise son sınıf öğrencilerinin ders dışı etkinliklere bakış açlarının incelenmesi (Ekici, Bayrakdar ve Oruç-Ugur, 2009), ders dişı sosyal (müziksel) etkinliklerin genel lise öğrencilerinin kural dışı davranış gösterme eğilimlerine etkisi (Apaydınlı ve Şentürk, 2012), ders dışı müzikal etkinliklerin ilköğretim 7. sınıf öğrencilerinin sosyalleşmelerine etkisi (Dinçer, 2009), okul yöneticilerin ders dişı etkinliklere yaklaşımları (Karaküçük, 1999), ortaöğretim öğrencilerinin ders dışı etkinliklere katılımının incelenmesi (Sarı, 2012), ders dışı sporla ilgili oyunların lise öğrencilerinin davranış örüntülerine etkisi (Soytürk ve Tepeköylü-Öztürk, 2020) gibi konuları ele alan araştırmalar olduğu görülmektedir 
Yurtdışı araştırmalar ele alındığında, program dışı etkinlilere katılımın akademik başarıyı olumlu yönde etkilediği (Cooper, Valentine, Nye ve Lindsay, 1999; Fredricks ve Eccles, 2006; Jansen, 2016; Marsh ve Kleitman, 2002; Meadows 2019; Moriana vd., 2006; Reeves, 2008), okulu terk etme oranlarını ve devamsızlıkları ve disiplin sorunlarını azalttı̆ı (Hill, 2010), risk altındaki öğrencilere okullarıyla olumlu yönde bağ oluşturma firsatı sunduğu (Fredricks ve Eccles, 2006; Holoway, 2002; Mahoney ve Cairns, 1997) belirlenmiştir. Lemmon (2019), boylamsal araştırmasında sanata dayalı program dışı etkinliklere katılan öğrencilerin daha sonra topluma hizmet çalışmalarına zaman ayırıp daha fazla gönüllü davrandıkları sonucuna ulaşmıştır. Haegele, Aigner ve Healy (2020), engelli ergenlerin program dişı etkinliklere katılımının zorbalık davranışlarının azalmasında etkili olduğu sonuçlarına ulaşmışlardir.

Yapılandırmacı anlayışla hazırlanan günümüz eğitim programlarında okulun yaşamın kendisi olarak görüldüğü bilinmektedir. Program dışı etkinliklerin de tam bu noktada önemli bir işlev görmesi beklenebilir. Çünkü bu tür etkinliklerde birey, bir ortamda nasıl davranması gerektiği, kazanma-kaybetme duyguların iyi yönetebilme, sorumluluk alma, kendine ve arkadaşlarına güvenme gibi davranış ve becerileri öğrenmektedir. Gerek sportif etkinlikler, gerek sanatsal etkinlikler, gerekse topluma hizmet çalışmalarında öğrenciler içinde yaşadığı topluma etkin bir biçimde katılmaktadırlar. Program dışı etkinliklerin uygulamada bazı zorluklarının olmasına karşın akademik başarıya, kişilik gelişimine, toplumsal ve bireysel değerlere, sorumluluk duygusunun oluşumuna, okul iklimi ve kültürünün olumlu yönde oluşmasına katkı vermesi açısından oldukça önemli olduğu yukarıda sözü edilen araştırmalardan anlaşılmaktadır. Program dışı etkinliklerin öğrenen üzerindeki bu tür katkılarının yanında, eğitim alanında alınan bazı karar ve uygulamalar da program dişı etkinlikleri daha önemli hale getirmektedir. İlk olarak MEB'in Eğitim Kurumları Sosyal Etkinlikler Yönetmeliği'ni 2017 yılında güncellemesi, Yükseköğretim Kurumu'nun (YÖK) 2018 yılında yeniden düzenlediği eğitim fakülteleri lisans programları alan seçmeli dersleri arasında Eğitimde Program Dışı Etkinlikler dersine de yer vermiş olması söylenebilir. Ayrıca MEB (2018) 2023 Eğitim Vizyonu belgesinde öğrenenlerin çok yönlü gelişimleri ile ilgili okul dışı öğrenme ortamlarına vurgu yapması ve öğrencilerin bu süreçlere katılımlarının ölçme değerlendirme kapsamında değerlendirilmeye dahil edilmesine yönelik önerileri, konunun araştırma konusu yapılmasında 
güncel durumu belirlemek açısından etkili olmuştur. Program dışı etkinliklerin okullar aracılığıyla daha geniş kitlelere yapılıyor olması ve bu etkinlikleri yürütmede öğretmenlerin önemli bir görev ve payının olması bu araştırmada öğretmenlerin görüşlerinin alınmasında etkili olmuştur. Bu bakımdan araştırmanın program dışı etkinliklerin güncel durumuna ilişkin katkı sağlaması beklenebilir. Bu araştırma, Milli Eğitim Bakanlığı Eğitim Kurumları Sosyal Etkinlikler Yönetmeliği tarafından okullarda uygulanması öngörülen program dışı etkinliklerin öğretmen görüşlerine göre değerlendirilmesini amaçlamaktadır. Bu amaç doğrultusunda aşağıdaki sorulara cevap aranmaya çalışılmıştır.

1. Okullarda gerçekleştirilen program dışı etkinlik türleri nelerdir?

2. Öğretmenler program dışı etkinlikleri nasıl değerlendirmektedirler?

3. Öğretmenlerin program dışı etkinliklerin planlama sürecine ilişkin görüşleri nelerdir?

4. Öğretmenlerin program dişı etkinlikleri uygulama sürecine ilişkin görüşleri nelerdir?

5. Öğretmenlerin program dişı etkinlikleri yürütürken paydaşlarıyla olan etkileşimlerine ilişkin görüşleri nelerdir?

6. Öğretmenlerin program dışı etkinlikler yoluyla öğrencilerin edindikleri kazanımlara ilişkin görüşleri nelerdir?

\section{Yöntem}

\section{Araştırma Modeli}

Bu araştırmada nitel araştırma modellerinden durum çalışması deseni kullanılmıştır. Nitel araştırmanın temelinde keşfetmek istenilen temel bir olgu vardır (Creswell, 2017), ayrıca nitel yöntemler derin ve ayrıntılı konularda çalışmaya imkân verir (Patton, 2018). Nitel yaklaşımlarda amaç belirli bir duruma ilişkin sonuçlar ortaya koymaktır. Nitel durum çalışmasının en temel özelliği bir ya da birkaç durumun derinliğine araştırılması (Yıldırım ve Şimşek, 2006), karmaşık, özel ve ilginç bir olgunun, durumun kendi koşulları içerisinde incelenmesidir (Sönmez ve Alacapınar, 2011). Durum çalışmaları yakınlık, gerçek ortamdaki davranış ve anlamı konusunda yeni bir şeylerin öğrenilmesine dayalı değerli ve derinlemesine anlamayı ortaya çıkarmayı amaçlar (Yin, 
2017). Creswell (2018), durum çalışması araştırmasında, araştırmacının gerçek yaşam, güncel sınırlı bir durum ya da belli bir zaman içinde durumlar hakkında çoklu bilgi kaynakları kullanılarak detaylı ve derinlemesine bilgi toplandığı, bir durum betimlemesi ya da durum temaları ortaya koyduğu nitel bir yaklaşım olduğunu belirtmiştir. Bu nedenlerle araştırmada, program dış1 etkinliklerin öğretmen görüşlerine göre kendi koşulları içerisinde derinlemesine araştırılıp incelenmesi amaçlandından durum çalışması deseni seçilmiştir. Araştırmanın durumu, program dışı etkinliklerin yapılandırılma biçimidir. Program dışı etkinliklerin planlama ve uygulanma süreçlerine ilişkin öğretmen görüşleri analiz birimini oluşturmaktadır.

\section{Çalışma Grubu}

Araştırmanın çalışma grubunu Burdur ilinde bulunan bir ilçede farklı lise türlerinde görev yapan öğretmenler oluşturmaktadır. Çalışma grubu oluşturulurken, amaçlı örnekleme yöntemlerinden maksimum çeşitlilik ve ölçüt örnekleme yöntemlerinden yararlanılmıştır. Maksimum çeşitlilik örneklemesinde amaç, göreli olarak küçük bir örneklem oluşturmak ve probleme taraf olabilecek bireylerin çeşitliliğini maksimum derecede yansıtmaktır (Yıldırım ve Şimşek, 2006). Araştırmada program dişı etkinliklerin nasıl yapılandırıldığını ortaya koymak için farklı lise türlerinde görev yapmakta olan öğretmenlerin görüşlerine başvurulmuştur. Ölçüt örnekleme mantı̆̆ı, önceden belirlenmiş bir önemdeki ölçütleri karşılayan tüm durumları gözden geçirmek ve incelemektir (Patton, 2018). Araştırmada belirlenmiş temel ölçüt öğretmenlerin görev yaptıkları okullarda program dışı etkinlik yürütmede görev almış olmalarıdır. Araştırmaya katılan öğretmenlere ait kişisel bilgiler Tablo 1'de verilmiştir. Patton (2018), geleneksel olarak araştırmacılara, katılımcıların kimliklerini korumak adına katılımcıların isimlerini değiştirerek takma ad kullanmalarını önermektedir. Bu araştırmaya katılan öğretmenlerin kimliklerini korumak için Ö1, Ö2, ...şeklinde kodlar kullanılmıştır. 
Tablo 1. Öğretmenlere İlişkin Kişisel Bilgiler

\begin{tabular}{lllll}
\hline Öğretmen & Cinsiyet & $\begin{array}{l}\text { Mesleki } \\
\text { Kıdem }\end{array}$ & Branş & Lise Türü \\
\hline Ö1 & E & 22 & Beden Eğitimi & Anadolu Lisesi \\
\hline Ö2 & K & 30 & Türk Dili ve Edebiyat & Fen Lisesi \\
\hline Ö3 & E & 13 & Beden Ĕ̈itimi & Mesleki ve Teknik Anadolu Lisesi. \\
\hline Ö4 & E & 4 & Meslek Dersleri & İmam-Hatip Lisesi \\
\hline Ö5 & E & 20 & Türk Dili ve Edebiyat & Anadolu Lisesi \\
\hline Ö6 & E & 26 & Meslek Dersleri & Mesleki ve Teknik Anadolu Lisesi \\
\hline Ö7 & E & 21 & Müzik & Fen Lisesi \\
\hline Ö8 & E & 22 & Beden Eğitimi & Fen Lisesi \\
\hline Ö9 & E & 20 & Tarih & Fen Lisesi \\
\hline Ö10 & E & 22 & Beden Eğitimi & Mesleki ve Teknik Anadolu Lisesi \\
\hline Ö11 & K & 19 & Görsel Sanatlar & Anadolu Lisesi \\
\hline Ö12 & E & 18 & Beden Eğitimi & İmam-Hatip Lisesi \\
\hline & & & &
\end{tabular}

Tablo 1 incelendiğinde, araştırmaya katılan öğretmenlerin onu erkek, ikisi kadındır. Bir öğretmen 1-5 yıl arası, bir öğretmen 11-15 yıl arası, dört öğretmen 16-20 yıl arası ve altı ögretmen de 21 yıl ve üzeri mesleki kıdeme sahiptir. Araştırmadaki öğretmenlerin beşi Beden Eğitimi, ikisi Mesleki Alan Dersleri, ikisi Türk Dili ve Edebiyatı, biri Müzik, biri Görsel Sanatlar ve biri Tarih branşındadır. Araştırmaya katılan tüm öğretmenler lisans düzeyinde eğitim durumuna sahiptir. Araştırmada dört öğretmen Fen Lisesinde, üç öğretmen Anadolu Lisesinde, iki öğretmen İmam-Hatip Lisesinde, üç öğretmen de iki farklı Mesleki ve Teknik Anadolu Lisesinde görev yapmaktadır.

\section{Veri Toplama Aracı}

Nitel araştırmalarda kullanılan görüşmelerin en güçlü özelliği göremediklerimiz hakkında bilgi edinme ve gördüklerimiz hakkında ise alternatif açıklamalar yapma firsatı vermeleridir (Glesne, 2015). Bu araştırmada veriler, araştırmacılar tarafından hazırlanan yarı yapılandırılmış görüşme formu kullanılarak elde edilmiştir. Yarı yapılandırılmış görüşme, araştırmacı tarafından önceden belirlenmiş yanıtlayıcının kısmen düzeltme, düzenleme hakkı olan ya da görüşme sırasında ortaya çkan konulara göre yeni soruların da sorulabildiği veya bazı soruları birlikte yeniden düzenleyebildiği bir görüşme yöntemi olarak nitel araştırmalarda yaygın olarak kullanılan bir veri toplama yöntemi veya tekniğidir (Güler, Halıcıoğlu ve Taşğın, 2015; Sönmez ve Alacapinar, 2011). 
Yarı yapılandırılmış görüşme formu alanyazın incelemesi ve alt problemlerin çerçevesinde araştırmaçlar tarafindan oluşturulduktan sonra, uzman görüşüne sunulmuştur. Uzman görüşüne dayalı olarak sorular üzerinde dil ortaklığı, açıklık, binişiklik açılarından düzenlemeler yapılıp program dışı etkinlik yürütmüş bir lise öğretmeni ile pilot uygulaması yapılmıştır. Pilot uygulama 38 dakika sürmüştür. Pilot uygulama sonrası, sorular, açıklık anlaşılırlık açısından da tekrar gözden geçirilerek görüşme formuna son şekli verilmiştir. Yarı yapılandırılmış görüşme formunda yer alan sorulardan bazıları şu şekildedir: Yürüttüğünüz program dışı etkinliklere ilişkin başta nasıl bir planlama yaptınız?, Program dışı etkinliklerinizi yürütürken öğrencilerle etkileşiminiz nasıldı? Bu etkinlikleri yürütürken velilerle nasıl bir etkileşim içerisindeydiniz?

\section{Verilerin Toplanması}

Araştırmanın verileri 2019-2020 güz yarıyılında (Aralık ayı içerisinde) toplanmıştır. Araştırmanın katılımcıları belirlenirken öncelikle farklı lise türlerinin okul yönetimleri aracılığıyla program dışı etkinlikleri yürütmüş öğretmenler belirlenmiştir. Daha sonra bu öğretmenler arasında görüşme için gönüllü katılım gösteren öğretmenlerle yer ve zaman ayarlaması yapılmıştır. Görüşmeler ögretmenlerin derslerini engellemeyecek zaman dilimlerinde ve mümkün olduğunca okullarında görüşmeye uygun ortamlarda yapılmıştır. Katılımc1larla yapılan görüşmeler, 23 ile 48 dakika aralıklarında değişen sürelerde gerçekleşmiştir. Görüşmelerde iki öğretmen ses kaydı yapılmasını istemediğinden not tutularak kayıt yapılmış, diğer öğretmenler ile yapılan görüşmelerde ses kaydı alınmıştır.

\section{Verilerin Analizi}

Araştırma verilerinin analizi, nitel veri analizi tekniklerinden içerik analizi kullanılarak yapılmıştır. İçerik analizi, belirli kurallara dayalı kodlamalarla bir metnin bazı sözcüklerinin daha küçük içerik kategorileri ile özetlendiği sistematik, yinelenebilir bir teknik olarak tanımlanır (Büyüköztürk, Kılıç Çakmak, Akgün, Karadeniz ve Demirel, 2018). İçerik analizinde temel amaç, toplanan verileri açıklayabilecek kavramlara ve ilişkilere ulaşmaktır. Betimsel analizde özetlenen ve yorumlanan veriler, içerik analizinde daha derin bir iş- 
leme tabi tutulur ve betimsel bir yaklaşımla fark edilemeyen kavram ve temalar bu analiz sonucu keşfedilebilir. İçerik analizinde temelde yapılan işlem, birbirine benzeyen verileri belirli kavramlar ve temalar çerçevesinde bir araya getirmek ve bunları okuyucunun anlayabileceği bir biçimde düzenleyerek yorumlamaktır (Yıldırım ve Şimşek, 2006). Bu araştırmada "tümevarımcı analiz" kullanılmıştır. Bu analiz yaklaşımında amaç, kodlama yoluyla verilerin altında yatan kavramlan ve bu kavramlar arasındaki ilişkileri ortaya çıkarmaktır. Ortaya çıkan kodlar (kavramlar) ve bu kodlar arasındaki ilişkiler (temalar), verilerin altında yatan olguyu ya da kuramı açıklamada kullanılan temel taşlar olarak görev yapmaktadır (Yıldırım ve Şimşek, 2006). İçerik analizi sürecinde şu adımlar takip edilmiştir: Öncelikle araştırmanın alt problemleri kapsamında genel bir tematik çerçeve belirlenmiştir. Bu bağlamda belirlenmiş başlıklar; program dişı etkinlikler, planlama süreci, uygulama süreci, okul paydaşlarıyla etkileşim süreci ve öğrenci kazanımları şeklindedir. Bilgisayar ortamına aktarılmış veriler dikkatli şekilde birkaç defa okunmuş ve kodlanmıştır. Ortaya çıkan kodlar listelenmiş ve örtüşen kodlar bir araya getirilerek alt temalar oluşturulmuş ve belirlenmiş genel tematik çerçevenin altında bütüncül olarak sunulmuştur.

\section{Geçerlik ve Güvenirlik}

LeCompe ve Goetz'e (1982) göre geçerlik, araştırma sonuçlarının doğruluğunu konu edinir. Dış geçerlik, elde edilen sonuçların benzer gruplara ya da ortamlara aktarılabilirliğine, iç geçerlik ise araştırma sonuçlarına ulaşırken izlenen sürecin çalışılan gerçekliği ortaya çıkarmadaki yeterliğine ilişkindir. Güvenirlik ise, kısaca araştırma sonuçlarının tekrar edilebilirliği ile ilgilidir. Dış güvenirlik, araştırma sonuçlarının benzer ortamlarda aynı şekilde elde edilip edilemeyeceğine, iç güvenirlik ise başka araştırmacıların aynı veriyi kullanarak aynı sonuçlara ulaşıp ulaşmayacağına ilişkindir (Akt: Yıldırım ve Şimşek, 2006).

Araştırmanın geçerlik ve güvenirlik çalışmasında Lincoln ve Guba (1985) tarafından önerilen "iç geçerlik" yerine "inandırıcılık", "dış geçerlik" (ya da "genelleme") yerine "aktarılabilirlik", "iç güvenirlik" yerine "tutarlık" ve "dış güvenirlik" (ya da "tekrar edilebilirlik") yerine "teyit edilebilirlik" (Akt: Yıldırım ve Şimşek, 2006) alternatif kavramları kullanılmıştır. 
Araştırmada inandırıcılığın sağlanabilmesi için öğretmenlerle 23-48 dakika sürelerle "uzun süreli etkileşim", farklı özelliklere sahip katılımcıların araştırmaya dâhil edilmesiyle "çeşitleme" ve araştırmadaki veriler ile bu verilere ilişkin sonuç ve yorumların veri kaynaklarıyla (katılımclarla) teyit edilerek "katılımcı teyidi" stratejileri kullanılmıştır. Araştırmada aktarılabilirliği sağlamak için amaçı̈ı örnekleme yöntemi kullanılmış, ayrıca elde edilen veriler derinlemesine analiz edilmiş ve bulgular bölümünde doğrudan alıntılara yer verilerek okuyucuya aktarılmıştır. Bu işlemler dikkate alındığında inandırıclığın ve aktarılabirliğin sağlanması bakımından araştırmanın geçerli olduğu söylenebilir.

$\mathrm{Bu}$ araştırmada teyit edilebilirliği sağlamak için araştırma sürecinde ses kaydı yapmayı kabul eden öğretmenlerle ses kaydı, bu şekilde bir kaydı kabul etmeyen öğretmenlerle de elle not alınarak görüşme kayıtları gerçekleştirilmiştir. Araştırmada iki öğretmen hariç diğer öğretmenlerle ses kaydı şeklinde görüşmeler kaydedilmiştir. Ham veriler analiz aşamasında açık kalmıştır. Bulgular sunulurken oluşturulan anlamlar ham veri metni ile karşılaştırılarak yazılmıştır. Ayrıca analiz aşamasında yapılan kodlamalar gerektiğinde böyle bir incelemeye sunulması için saklanmıştır. Son olarak araştırmada tutarlığın sağlanması için elde edilen veriler analiz edilirken araştırmacılar kendi içinde kodlamada tutarlı olmuş ve tesadüfi seçilen iki veri seti iki araştırmacı tarafından kodlanmış ve güvenirlik katsayısı hesaplanmıştır. Daha sonra iki araştırmacı tarafından yapılan analizler arasında tutarlık incelemesi yapılmıştır. Güvenirlik katsayısını hesaplamada, Miles ve Huberman (2016) tarafından geliştirilen $\mathrm{P}=(\mathrm{Na} / \mathrm{Na}+\mathrm{Nd}) \times 100$ formülü kullanılmıştır. Hesaplama sonucunda, iki araştırmacı arasında birinci görüşme (Ö2) kaydına ait \% 85,36, ikinci görüşme (Ö8) kaydına ait \% 84,78 oranında uyum belirlenmiştir. Yıldırım ve Şimşek (2006), birden fazla araştırmacının veri analizinde birlikte çalıştığ 1 durumlarda, kodlama güvenirliğinin en az \% 70 düzeyinde bir güvenirlik yüzdesine ulaşmak gerektiğini belirtmiştir. Bu bakımdan araştırmada verilerin kodlama tutarlığın sağlandığı ve araştırmanın güvenilir olduğu söylenebilir.

Tablo 2. İki Kodlayıcı Arası Güvenirlik

\begin{tabular}{llll}
\hline Veri Seti & Görüş Birliği Sayısı (Na) & Görüş Ayrılı̆̆ı Sayısı (Nd) & Güvenirlik (P) \\
\hline Ö2'ye iliskkin görüşme kaydı & 35 & 6 & 85,36 \\
\hline Ö8'e ilişkin görüşme kaydı & 39 & 7 & 84,78 \\
\hline
\end{tabular}




\section{Bulgular}

Bu bölümde öğretmenlerin "program dışı etkinliklere" ilişkin görüşlerine ilişkin bulgular alt problemlere göre başlıklar altında verilmiştir.

\section{Okullarda Uygulanan Program Dışı Etkinlik Türleri}

Araştırma kapsamında bulunan okullarda gerçekleştirilen program dışı etkinlik türleri Tablo 3'te verilmiştir.

Tablo 3. Liselerde uygulanan program dışı etkinlik türleri

\begin{tabular}{|c|c|c|c|c|c|}
\hline & $\begin{array}{l}\text { Bilimsel } \\
\text { Etkinlik }\end{array}$ & $\begin{array}{l}\text { Kültürel } \\
\text { Etkinlik }\end{array}$ & $\begin{array}{l}\text { Sanatsal } \\
\text { Etkinlik }\end{array}$ & $\begin{array}{l}\text { Sportif } \\
\text { Etkinlik }\end{array}$ & $\begin{array}{l}\text { Topluma Hizmet } \\
\text { Çalışmaları }\end{array}$ \\
\hline Fen Lisesi & -Münazara & -Geziler & -Şiir Dinletisi & $\begin{array}{l}\text {-Masa Tenisi } \\
\text {-Voleybol } \\
\text {-Satranç }\end{array}$ & \\
\hline Anadolu Lisesi & $\begin{array}{l}\text {-TÜBİTAK } \\
\text { Bilim Fuarı } \\
\text {-Münazara }\end{array}$ & $\begin{array}{l}\text {-Halk } \\
\text { Oyunları } \\
\text {-Aşure Günü } \\
\text { Etkinlikleri }\end{array}$ & $\begin{array}{l}\text {-Resim Sergisi } \\
\text {-Tiyatro } \\
\text {-Müzik Şöleni }\end{array}$ & $\begin{array}{l}\text {-Futsal } \\
\text {-Voleybol } \\
\text {-Basketbol }\end{array}$ & \\
\hline $\begin{array}{l}\text { İmam-Hatip } \\
\text { Lisesi }\end{array}$ & $\begin{array}{l}\text {-TÜBİTAK } \\
\text { Bilim Fuarı } \\
\text {-Münazara }\end{array}$ & $\begin{array}{l}\text {-Yurdumun } \\
\text { Değerleri }\end{array}$ & $\begin{array}{l}\text {-Genç } \\
\text { Musiki Etkinliği }\end{array}$ & $\begin{array}{l}\text {-Futsal } \\
\text {-Voleybol }\end{array}$ & $\begin{array}{l}\text {-Yedi Güzel Adam } \\
\text { Camide }\end{array}$ \\
\hline $\begin{array}{l}\text { Mesleki ve } \\
\text { Teknik } \\
\text { Anadolu } \\
\text { Lisesi }\end{array}$ & -Münazara & $\begin{array}{l}\text {-Aşure Günü } \\
\text { Etkinlikleri }\end{array}$ & $\begin{array}{l}\text {-Belirli Gün } \\
\text { ve Haftalarla } \\
\text { İgili Çalışmalar } \\
\text {-Sinema Günleri }\end{array}$ & $\begin{array}{l}\text {-Futsal } \\
\text {-Voleybol }\end{array}$ & $\begin{array}{ll}\text {-Meslek } & \text { Liseliler } \\
\text { Ailelerle } & \text { Buluşu- } \\
\text { yor } & \end{array}$ \\
\hline $\begin{array}{l}\text { Mesleki } \\
\text { ve Teknik } \\
\text { Anadolu Lisesi }\end{array}$ & & & & -Futsal & \\
\hline
\end{tabular}

Tablo 3 incelendiğinde okullarda beş etkinlik kategorisi altında toplamda 20 program dişı etkinlik yürütüldüğü, okul bazında en fazla yedi en az bir etkinliğin yürütülmüş olduğu görülmektedir. Etkinlik kategorilerine göre bakıldığında, bilimsel etkinlik kategorisi kapsamında "münazara" ve "TÜBİTAK bilim fuarı" olmak üzere iki tür etkinliğin gerçekleştirilmiş olduğu görülmektedir. Okul yöneticileri münazaraların il milli eğitim müdürlüğü tarafından yürütülen Başarıyı İzleme ve Geliştirme Projesi (BIGEP) kapsamında yapıldığını ve münazaraların birkaç ay koordinatör öğretmen eşliğinde çalışmaların yürütüldüğünü belirtmişlerdir. Ayrıca TÜBİTAK bilim fuarı için proje 
başvurularının yapıldığını fakat başvurularının kabul edilmediğinden bahsetmişlerdir. Kültürel etkinlik kategorisinde "geziler, halk oyunları, aşure günü etkinlikleri ve yurdumun değerleri" olmak üzere yalnızca dört etkinliğin yapılmış olduğu görülmektedir. Okul yöneticileri, gezilerin daha çok üniversite tanıtımları için yapıldığını, halk oyunlarını milli bayramlar için hazırlanma anlamında çalışmaların yapıldığını, aşure günü etkinliğinin ise bir ay öncesinden planlandığ 1 ve bu etkinlik için bir öğretmen görevlendirildiğini, öğrencilerden gönüllü olanların bu öğretmenle işbirliği içinde çalışmalarının sağlandığını belirtmişlerdir. Tabloda sanatsal etkinlik olarak "şiir dinletisi, tiyatro, resim sergisi, müzik şöleni (orkestra çalışması), genç musiki etkinliği, belirli gün ve haftalarla ilgili çalı̧malar ve sinema günleri" gibi etkinliklerin yapıldığı görülmektedir. Sportif etkinlik olarak ise masa tenisi, voleybol, futsal ve satranç etkinlikleri yapılmaktadır. Topluma hizmet çalışmalarında "Yedi Güzel Adam Camide" ve "Meslek Liseliler Ailelerle Buluşuyor" etkinliklerinin yapıldığı tabloda görülmektedir. Sportif etkinlikler tüm liselerde yapılan etkinlik türü olarak yer almaktadır.

\section{Program Dışı Etkinliklere Yönelik Öğretmen Görüşleri}

Araştırmaya katılan öğretmenlerin program dişı etkinlikleri "öğrenci boyutu", "öğretmen boyutu", "okul boyutu", "toplumsal boyut" ve "program boyutu" şeklinde olmak üzere beş kategoride değerlendirdikleri belirlenmiştir. İlk dört boyutun program dışı etkinliklerden beklenen olası yararlar (sonuçlar) oluştururken, beşinci boyutu sürece ilişkin değerlendirmeler (öneriler) oluşturmaktadır (Tablo 4).

Öğretmenler program dışı etkinlikleri; öğrencilerinde özgüven gelişimi, sosyalleşme, sorumluluk duygusu kazanma, meydana gelebilecek olumsuz davranışları engelleme, fiziksel gelişimlerini destekleme, yeni öğrenmeler sağlama, kendilerini yetiştirme ve geliştirme imkânı sunduğunu, bu tür etkinliklerle öğrencilerini her yönüyle tanıma firsatı bulduklarını ve okul iklimine de olumlu katkı sunmasından dolayı yapılmasını önemsediklerini belirtmişlerdir. Ayrıca program dışı etkinliklere daha fazla zaman ayrılması, eğitimin sadece derslerle sınırlı olmaması, maddi olanakların arttırılması, kapsamının genişletilmesi gerektiğini de belirtmişlerdir. 
Tablo 4. Öğretmenlerin program dışı etkinlikleri değerlendirmelerine ilişkin görüşleri

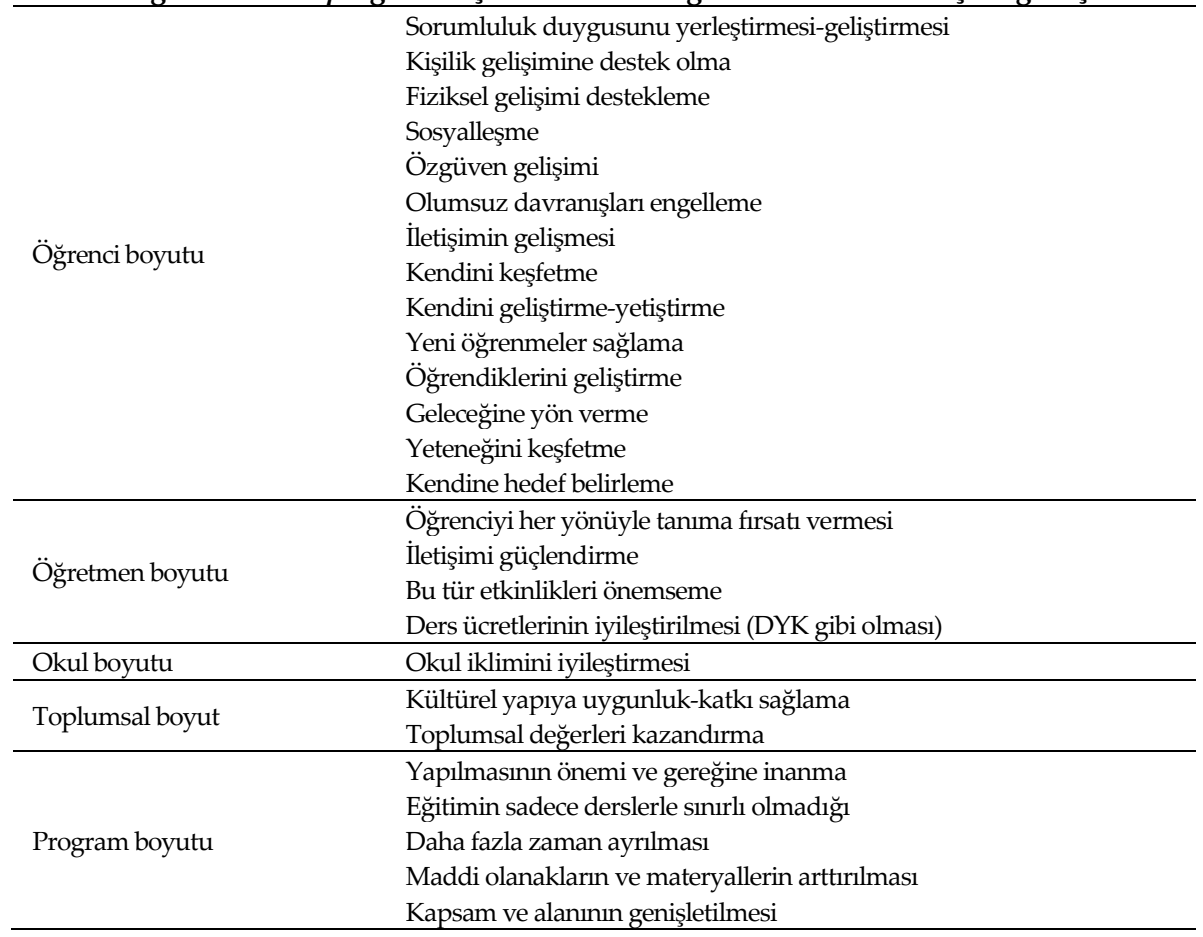

Araştırmada "program dişı etkinlikler" yönelik öğretmen görüşlerinden bazıları şu şekildedir:

- "Bu tür ders dışı etkinliklerin arttırılması düşüncesindeyim. Eğitim sadece akademik dersler üzerinde değil, disiplin sorunu olan, her konuda olmasa da bir alanda kendini geliştirebilecek imkân sağlaması noktasında bu tür ders dışı etkinlikleri faydal görüyorum. Bu etkinliklerde akran eğitimini, sorumluluk alma duygusunu, görev bilincini, kendini anlama ve gerçekleştirme yönünde katkıları olduğunu düşünüyorum." (Ö4)

- Ders dışı egzersiz çalışmalarına gereken önemin verilmediğini düşünüyorum. Şuna inanıyorum öncelikle. Çocuklarm eğitiminin sadece dersle, akademik başarryla olduğuna inananlardan değilim. Daha çok eğitim ile öğretimin birlikte her yönüyle sosyal, kültürel, sportif, akademik olarak birlikte yürütülürse daha başarılı olacağını düşünüyorum." (Ö8)

- "Ben bu çocuklara bu faaliyetlerin çok şey kattığını düşünüyorum. Ben 22 yıllık öğretmenim mesela. Çocuklarm özgüven yükselmesi, dersleri olumlu etkilemesi, 
okulu olumlu etkilemesi, hatta o antrenman saatinde bıraktığım zaman dışarıda belki kafelerde bunu bazı velilerden duyuyorum, hocam işte dışarıda kafeye gideceğine sizin antrenmanda olsun gibilerden mesele bazı velilerden duyunca da insanın hoşuna gidiyor." (Ö1)

- "Bu tip etkinlikler, çocuklara farklı bir yön veriyor. Bazı çocuklara artı yönden çok olumlu. Birebir iletişim ders dışı egzersizler zamanında daha farkh oluyor. Farklı şeyler konuşabiliyorsun, farklı şeyler karşılıklı diyaloglar kurabiliyorsun. O çocuk kendini farklı şekilde ifade edebiliyor. Ders dışı egzersizler çocukla iletişimin bir üst kademesi gibi oluyor, okul dışında olduğu için. Çocuğu anlama bakımından, ailevi durumundan biraz ipucu veya başka sosyal yönden, ekonomik yönden daha iyi tanıyoruz." (Ö10)

- "Bu tür etkinlikler yapılması gerekiyor. Öğrenci istekliyse gayet isabetli oluyor bu etkinlikler. Kendini geliştirebilir. Bilmediği bir alanda veya ilgi duyduğu alanlarda kendini yetiştirebilir, geliştirebilir. Geleceğine yön verebilir. Mesela, kendinle ilgili bir yeteneğini keşfedebilir. Mutlu olacağı bir mesleği seçer. Kendine hedefkoyabilir. Toplumun kültürel yapisinda olumlu katkılar oluyor. Fiziksel ve kişisel gelişimine olumlu katkısı var. Öğrenci kendisini keşfediyor, yapabileceklerini keşfediyor. Yeni davranışlar ediniyor." (Ö7)

\section{Uygulama Sürecine Yönelik Öğretmen Görüşleri}

Araştırmaya katılan öğretmenlerin program dişı etkinlikleri planlama sürecine ilişkin görüşleri Tablo 5'te verilmiştir.

Tablo 5. Öğretmenlerin planlama sürecine ilişkin görüşleri

\begin{tabular}{ll}
\hline \multirow{2}{*}{ Yapılan etkinlikler } & $\begin{array}{l}\text { Sportif etkinlikler } \\
\text { Sanatsal etkinlikler } \\
\\
\text { Topluma hizmet uygulamaları }\end{array}$ \\
\hline \multirow{2}{*}{ Etkinliği belirleme süreci } & Öğretmenin karar vermesi \\
& $\begin{array}{l}\text { Okul idaresinin karar vermesi } \\
\text { Öğrenci ile birlikte karar verme }\end{array}$ \\
\hline \multirow{2}{*}{ Planlama } & Okul ve Milli Eğitim Müdürlü̆ü onaylı yıllık plan \\
& Okul dışı paydaşlarla gerekli izinlerin alınması \\
\hline \multirow{2}{*}{ Uygulama durumu } & Plana sadık kalma \\
& Yapılamayan dersleri telafi etme \\
\hline
\end{tabular}

Tablo 5 incelendiğinde araştırmaya katılan öğretmenlerin program dişı etkinlikleri planlama sürecini "yapılan etkinlikler", "etkinliği belirleme süreci", 
"planlama" ve "uygulama durumu" şeklinde olmak üzere dört kategoride belirledikleri görülmektedir. Öğretmenlerle yapılan görüşmelerde lise türlerinin hepsinde sportif etkinlik olarak voleybol, futsal, masa tenisi, basketbol ve satranç etkinliklerinden mutlaka en az birisinin yapıldığı görülmüştür. Sanatsal etkinlik olarak Anadolu Lisesi ve Fen Lisesinde şiir dinletisi, tiyatro, resim sergisi ve orkestra çalışması, topluma hizmet uygulamaları kapsamında ise İmam-Hatip Lisesi "Yedi Güzel Adam Camide", Sağlık Meslek Lisesi de "Meslek Liseliler Ailelerle Buluşuyor" projelerini yaptıkları görülmüştür. Öğretmenlerin çoğunluğu etkinliklere öğrenci ile beraber karar verdiklerini, bazı öğretmenler ise, kendilerinin veya okul yönetimlerinin karar verdiklerini söylemişlerdir. Ayrıca program dişı etkinlik yapan öğretmenler yaptıkları planları onaylattıktan sonra sürece başladıklarını, yaptıkları plana sadık kaldıklarını ve mecburi sebeplerden dolayı yapılamayan dersleri de telafi ettiklerini belirtmişlerdir.

Araştırmada "planlama süreci" temasına yönelik öğretmen görüşlerinden bazıları aşağıda verilmiştir.

- "Satranç egzersizi. Etkinliği ben belirledim. İdare ve öğrenciler arasindan bir istek gelmedi. Ben kendim istedim. Bundan önceki görev yaptığım okulda arkadaşlarla satranç etkinliği yapardık, öğrencilerden de istekli olanlar vardı. Aynı egzersizi orada da yapmıştım. Bu okulda kendim belirledim." (Ö9)

- "Şiir dinletisi ve drama türünde etkinlikler yaptım yılsonu gecesi ile ilgili bir yıl boyunca çalışmamızı devam ettirdik. Tabi ki bunda en büyük etken öğrencilerin bu konuda hevesli olması, öğrencilerden talep gelmesi. Öğrencinin talebi doğrultusunda "hocam tiyatro yapalım, drama yapalım" diye talep geldi. Öğrencilerin talepleri doğrultusunda bu yılsonu gecesine bir yıl boyunca hazırlandık. Öğrenciden talep geldi dolayısıyla biz de bu talebi idareye söyledik, idare de bizi teşvik etti, destekledi yani olumlu baktı. Biz de bu şekilde başladık çalışmalarımıza." (Ö5)

- "Milli Eğitim Bakanlı̆̆ın okullarımı ailelerle buluşuyor projesi kapsaminda bir çalışma yapma kararı aldık. Çalı̧manın konusu benim tarafimdan belirlendi. Ne yapılacağı, hangi hizmetlerin yapılacağı ya da ailelere nasıl bir yardım edileceği." (Ö6)

- "Bizim sosyal etkinliklerde genellikle ders dışı çalışmalarda ders planlarımız vardir. Bu planlar doğrultusunda katılacağımız branşlar doğrultusunda planlar oluştururuz okul idaremize sunarı. Okul idaremiz ilçe milli eğitimden onayı aldıktan sonra biz çalışmalarımıza başlarız. Haftalık olarak düzenli yapabiliyoruz. 
Genellikle yapamadığımız olmuyor. Hastalık, sağlık, belirli zorunlu hallerde muhakkak etkinliği tekrardan başka bir gün içinde veya o haftanın veya bir sonraki haftanın başka bir gün içinde tekrardan tekrarlayabiliyoruz. Telafi ediyoruz." (Ö3)

- "Ders dışı egzersiz planlaması şeklinde yıllık olarak planlamamızı yaptık. Önce okul idaresi daha sonra İlçe Milli Eğitim Müdürlüğ̈̈nün onayından sonra çalışmalarımıza başladık. Her hafta bu plana düzenli olarak uyduk. Yapamadı̆̆ımız saatler de oldu ama diğer günler bu yapamadığımı çalışmaları telafi ettik." (Ö7)

\section{Planlama Sürecine Yönelik Öğretmen Görüşleri}

Araştırmaya katılan öğretmenlerin program dışı etkinlikleri uygulama sürecine ilişkin görüşleri Tablo 6 ' da verilmiştir.

Tablo 6 incelendiğinde araştırmaya katılan öğretmenler görüş̧lerini program dışı etkinliklerin uygulama sürecini "öğrenci katılım amacı", "öğrenci istekliliği", "okulun fiziksel koşulları" ve "karşılaşılan zorluklar" kategorileri altında bildirdikleri görülmektedir. Araştırmada öğretmenler öğrencilerin kendini keşfetme, özgüven kazanma, çevresine kendini gösterme, sosyal bir etkinlikte yer alma, diğer derslerden sıkılma, olumsuz imajların düzeltme gibi amaçlarla uygulama sürecinde yer aldıklarını; öğrencilerin istekliliği konusunda ise etkinliği önemsemeleri, etkinliği beraber planlamaları, devam konusunda özen göstermeleri, başarma duygusunun egemen olması, etkinliğe katılımda başka işleri olsa dahi ısrarcı olmaları yönünde görüş bildirmişlerdir. Okullarının fiziki koşulları, kapalı spor salonu ve atölye bulunmaması, materyal yetersizlikleri, velinin ve toplumun olumsuz bakış açısı, taşımalı gelen öğrenciler, zaman sıkıntısı, öğrencilerin ders yoğunluğunun fazla olması, aileye maddi külfette bulunması gibi nedenlerle program dışı etkinlikleri uygularken bazı zorluklarla da karşılaştıklarını belirtmişlerdir. 


\section{Tablo 6. Öğretmenlerin uygulama sürecine ilişkin görüşleri}

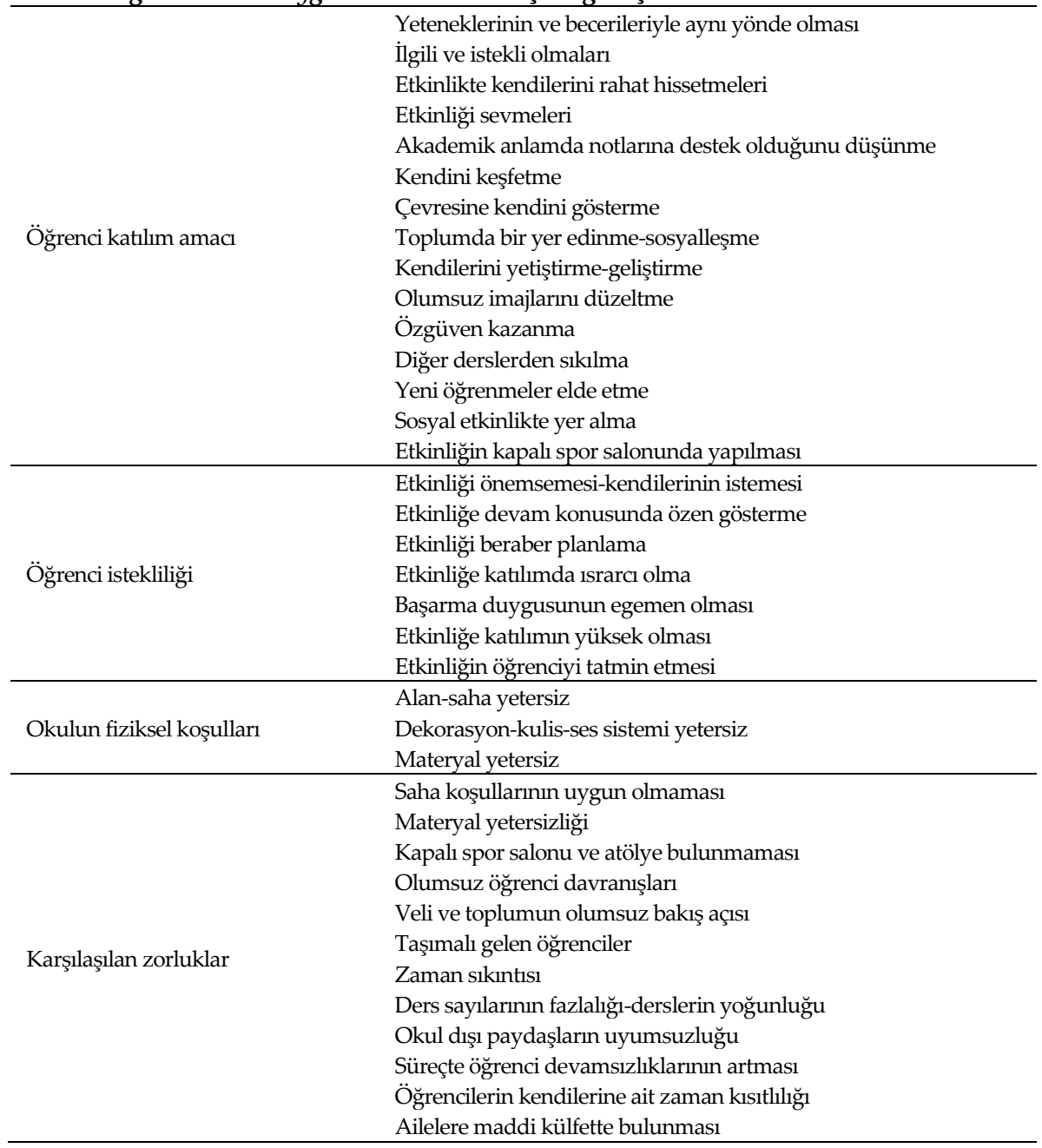

Araştırmada "uygulama süreci" temasına yönelik bazı öğretmen görüşleri şunlardır:

- "Çocuk arkadaşları ve toplum önünde kendini kanitlamak istiyor. Ayrıca, yoğun ders programı haricinde bir nebze olsun sosyal anlamda kendini geliştirmek ve deşarj olmak istiyor. Kendine güven duygusunu arttırma isteği, arkadaşlarn tarafindan kabul edilme amaçh etkinliklere katıldığını düşünüyorum." (Ö12) 
- “Ilk başlarda enstrüman çalmayı öğrenmek isteyenler, kendini bu konuda denemek isteyenler, aktivite olsun şeklinde düşüneneler katıllyor. Çalabildiğini gördükçe de kendi yeteneklerinin farkına vartyor. Artık daha rahat çalmaya başlıyor. Öz güven, kendini gösterme, topluma bir şeyler yapabildiğini gösterme duyguları süreç içinde çocukta oluşuyor." (Ö7)

- “Öğrenciler istekli, hoşuna gidiyor. Mesela yarışmaya gideceğiz Burdur iline 4 Mart'ta şiir dinletisi. "Bir şiir bir nefes" yarışmasına gideceğiz. Çocuklar harika beşöğrenciyle çalışıyorum. Şimdi beşini bir çalışttruyorum ki rekabet olsun diye. O kadar etkileniyor o kadar hırslanıyorlar ki başar istiyorlar sesleriyle müzikleriyle. Başka programlarmı iptal ediyorlar. Şu andaki çalışmamda Kimya kursundan gelecekler. Çünkü tiyatroya başlayacağız dediğim an gönüllü geliyorlar. Btrakıp gelebiliyorlar yani." (Ö2)

- “Öğrencilerimiz bizden istekliydi. Hatta hani dedim ya yerel yönetimle irtibat kurmada 15-20 günlük bir süre uzadı. Gelip sık sık sordular, hocam ne zaman başlıyoruz öğretmenim ne zaman başlyyoruz. Onlar bizden daha istekliydi. Süreç boyunca da iyiler. Şu an devam ediyor projemiz zaten. Biz 6 öğrencimiz var projeye katılan. Bu 6 öğrencimiz sirayla gidiyorlar, ailelere strayla gidiyorlar. Çocuklar her seferinde "Hocam biz de gitsek, biz de gitsek, tamam stra bizde değil ama biz de gelelim". İstekleri gayet motivasyonlar yüksek." (Ö6)

- "Bizim özellikle okul saha şartlarımız zayıf olduğu için mesela özellikle soğuklarda, yağmurda, çamurda bizim zorluklarımı bunlar oluyor." (Ö1)

- "Tabi ki bizim için tiyatro etkinliğinde en büyük sorun fiziki yetersizlikler. Maalesef bunu yaşıyoruz. Mesela tiyatro alanın çok dar olması, dekorasyon yetersizliği, en önemlisi ses sisteminin olmamast. Özellikle çok büyük bir etken. Ön klsımdakiler sesi duyuyor, arka taraftakiler duymuyor. Diğgr büyük sıkıntımı zaman. Özellikle taşımalı öğrencilerin gelip gitmesi, servislerin beklemesi sıkıntı." (Ö5)

- "Bence resim masrafl bir etkinlik. Maddi anlamda zor bir branş. Çocuklarm maddi durumlarmın iyi olması gerekiyor. Okulun atölyesinin bulunmaması diğer bir zorluk" (Ö11).

\section{Okul Paydaşlarnyla Olan Etkileşim Sürecine Yönelik Öğretmen Görüşleri}

Araştırmaya katılan öğretmenlerin program dişı etkinlikleri yürütürken paydaşlarıyla olan etkileşim sürecine ilişkin görüşleri Tablo 7'de verilmiştir. 
Tablo 7. Öğretmenlerin paydaşlarıla olan etkileşimlerine ilişkin görüşleri

\begin{tabular}{|c|c|}
\hline \multirow{5}{*}{ Öğrenci etkileşimi } & Kendilerini yakın hissetme \\
\hline & Rahat ve olumlu iletişim kurma \\
\hline & Duygusal bă̆ kurma \\
\hline & Samimi bir ortam \\
\hline & Birebir iletişim \\
\hline \multirow{6}{*}{ Okul yönetimi etkileşimi } & Masrafları karşılama-malzeme desteği verme \\
\hline & Sürekli iletişim halinde olma \\
\hline & Öğretmen ve öğrenciye güvenme \\
\hline & Etkinliklere olumlu bakma-katılma-izleme \\
\hline & Uygun çalışma ortamları sunma \\
\hline & Gerekli izinlerin alınmasinda öncülük etme \\
\hline \multirow{4}{*}{ Veli etkileşimi } & İzin noktasında destek olma \\
\hline & Süreç başında isteksizlik \\
\hline & Süreç sonunda olumlu bakış açısına sahip olma \\
\hline & Çocuğunun katilmasında israrcı olma \\
\hline
\end{tabular}

Tablo 7 incelendiğinde araştırmaya katılan öğretmenler program dışı etkinliklerde paydaşlarıyla olan etkileşim sürecinde okul yönetimlerinin kendilerine her konuda maddi-manevi destek olduğunu, öğrencileriyle aralarında olumlu bir iletişim ve ortam sağladıkların, bazı velilerle sürecin başında sıkıntılar yaşadıklarını fakat süreç boyunca veya sonunda olumlu dönütler aldıklarını, hatta bazı velilerin çocuklarını bu etkinliklere katılmasında ısrarcı olduklarını belirtmişlerdir.

Araştırmada "paydaşlarıyla olan etkileşim" temasına yönelik öğretmen görüşlerinden bir kısmı aşağıda verilmiştir.

- “Okul idaresi her türlü yanımızdaydı. Başlangıçta okul idaresiöncülü̈̆ünde başlattık. Her programımızda özellikle ulaşım noktasında, yemek konusunda ve gerekli izinlerin alınmasinda her zaman yanımizdaydı. Bizi destekledi. Toplum nezdinde projenin diri kalmasını ve gündemde tutulmasını sağladı. Gerekli dönütleri toplumdan alarak bize de ulaştırdi. Bu da motivasyonumuzun artmasina vesile oldu. Maddi-manevi her türlü destek aldığımızı düşünüyorum. Camide bütün programlarımıza katılarak bizleri orada da yalnız bırakmadı." (Ö4)

- IIdareden her türlü desteği aldlk. Să̆ olsun müdürümüz bu konuda özellikle istekli ve seviyor. Yeter ki öğrencilerimiz bir etkinliğg katılsın, ders haricinde bir etkinlikte bulunsun düşüncesine sahipler." (Ö9)

- "Velilerimiz önce şüpheliydi, şüpheciydi. Yani bu öğrenci ne yapacak? Bizde öğrencinin büyük bir bölümü kızdır, kız öğrenci. Toplumsal açıdan baktığınızda kız öğrencinin görev alacağı alanlar aileler tarafindan önce güvensizlikle karşılanıyor. Sonra konu iletildiğinde, anlatıldı̆̆ında hepsi "katılsın" dediler. Biz aileler- 
den izin belgesi aldık. Olumsuz yönde bir dönüt olmadı. Olumlu yönde çocuklarımız gerçek vakalarla doğrudan karşılaştıklarında insan ki bu insanlar yatalak insanlar evde bakım hastalar. Evdeki ihtiyarlara daha sevgiyle ya da daha anlayışla yaklaştıklarını söylediler." (Ö6)

- "SSimdi şöyle söyleyeyim. 298-300 civarmda öğrencimiz var. Ben en iyi diyalog kurduğum öğrenciler egzersiz çalışmalarm yürüttü̈̆̈̈m öğrenciler. Çocuklar şöyle söyleyeyim, o öğrenciler daha samimiler. Diğer öğrenciler gibi uzaktan geçmiyor, gelip hal hatır soruyor, muhabbet ortamı oluşturuyor. Daha çok yakı hissediyorlar. Diğer öğrencilerin yaşamış olduğu kanımca çekinme, çekintiyi yaşamıyorlar. Bunun sebebi aramızdaki ilişki artık öğretmen-öğrenci ilişkisinden çıkıyor biraz daha böyle abi-kardeş, usta-çırak şeyi oluyor artık. Ona farkh bir şey öğretebiliyorsan çocuk bunu farklı yönde algillyor. Bunu bir eğitim, ders gibi görmüyor bunu zaten. Kendini yetiştirme anlammda, bir becerisini geliştirme anlaminda görüyor." (Ö8)

\section{Öğrenci Kazanımlanına Yönelik Öğretmen Görüşleri}

Araştırmaya katılan öğretmenlerin program dışı etkinlikler yoluyla öğrencilerin edindikleri kazanımlara ilişkin görüşleri Tablo 8' de verilmiştir.

Tablo 8'e göre öğretmen görüşlerine göre program dışı etkinlikler yoluyla öğrencilerin sağladığı kazanımları; okul kültürü, akademik, psikolojik, fiziksel ve sosyal yönlerden gelişim ve bu etkinlikler neticesinde bir ürün veya performans ortaya koymaları şeklinde kazanımlar elde ettiklerini belirtmişlerdir. Öğrencilerin bu tür etkinliklerle okula aidiyet duygularının geliştiğini, devamsızlıklarında azalma olduğunu ve olumsuz davranışlarında da düzelmeler meydana geldiğini söylemişlerdir. Akademik yönden derslere olan ilginin artacağına inanan öğretmenler, mesleki farkındalığın oluşmasına ve zekâ gelişimini de desteklediğini düşünmektedirler. Ayrıca program dışı etkinliklerin öğrencileri zihinsel yönden rahatlattığı, zor durumlarda karar verebilme yetilerini geliştirdiği, kemik-kas yapısını güçlendirdiği, zamanla toplum içinde kendilerini rahat bir şekilde ifade etmeye başladıklarını, bir ürün ortaya koyunca veya derece elde ettiklerinde başarma duygusunu kazandıklarını ve mutlu olduklarını da belirtmişlerdir. Tüm bu olumlu yönlerine rağmen bazı öğrencilerin bu tür etkinlikleri derslerden kaytarma olarak gördüklerini, yaş grubu itibariyle arkadaşlarının gözünde etkinlikte yer almanın vermiş olduğu popüler görülmeyi yanlış yönde kullanabildiklerini de vurgulamışlardır. Öğrenci katılımının ve elde ettiği kazanımları e-okul sisteminde 
kayıt altına alınma şeklini öğretmenlerin yeterli bulmadığı ve e-okul sisteminde yer alan sosyal etkinliklere katılım bölümünün kapsamının genişletilmesini, öğrencilere ileriki eğitim yaşamlarında referans görevi görmesini, hatta gireceği sınavlarda ek puan verilerek desteklenmesi gerektiğini söylemişlerdir.

\section{Tablo 8. Öğretmenlerin öğrenci kazanımlarna ilişkin görüşleri}

\begin{tabular}{|c|c|}
\hline \multirow{4}{*}{ Okul kültürü } & Okula aidiyet duygusunun gelişmesi \\
\hline & Okulu sahiplenme-temsil etme \\
\hline & Devamsızlıklarda azalma-düzelme \\
\hline & Olumsuz davranışlarda düzelme-disiplin \\
\hline \multirow{7}{*}{ Akademik gelişim } & Derslere olan ilginin artacağına inanma \\
\hline & Okul takımından ayrılma endişesiyle derslere yönelme \\
\hline & Zekâ gelişimini desteklemesi \\
\hline & Dikkatli davranma ve planlı yaşamayı öğrenme \\
\hline & Birbirleriyle olan iyi iletişim sonucu dersleri iyi dinleme \\
\hline & Mesleki farkındalığının oluşması \\
\hline & Dersleri ihmal edebilme-kaytarma \\
\hline \multirow{9}{*}{ Psikolojik gelişim } & Negatif enerjinin atılması \\
\hline & Zihinsel rahatlama \\
\hline & Özgüven gelişimi \\
\hline & Motivasyonda artma \\
\hline & Zor durumlarda karar verebilme \\
\hline & Sabırlı olmayı öğrenme \\
\hline & Zorluklarla başa çıkabilme \\
\hline & Başarma duygusu \\
\hline & Sorumluluk sahibi olma \\
\hline \multirow{3}{*}{ Fiziksel gelişim } & Kemik-kas yapısının güçlenmesi \\
\hline & Dolaşım ve boşaltım sistemlerinin düzene girmesi \\
\hline & Ses şiddetini-tonunu ayarlayabilme \\
\hline \multirow{5}{*}{ Sosyal gelişim } & Arkadaşlık bağlarında güçlenme \\
\hline & Birlikte yaşama duygusu \\
\hline & Toplum içinde kabul görme \\
\hline & Toplum içinde kendini ifade edebilme \\
\hline & Popülariteyi yanlış kullanabilme \\
\hline \multirow{6}{*}{ Ürün-Performans ortaya koyma } & Resim sergisi \\
\hline & Şiir dinletisi \\
\hline & Tiyatro sahneleme \\
\hline & Derece elde etme \\
\hline & Madalya kazanma \\
\hline & Sadece etkinliğe katılma \\
\hline \multirow{8}{*}{ E-okul boyutu } & Kapsamı genişletilmeli \\
\hline & Ödüllendirilmeli \\
\hline & İlgilerine ve yeteneklerine göre yönlendirilmeli \\
\hline & Referans olarak kullanılmalı \\
\hline & Akademik olarak ek puanlar verilmeli \\
\hline & Öğrencinin yaptıkları detaylı olarak açıklanmalı \\
\hline & PDE katılanlar desteklenmeli \\
\hline & Öğretmenin herhangi bir bilgisi yok \\
\hline
\end{tabular}


Araştırmada "öğrenci kazanımları" temasına yönelik öğretmen görüşlerinden bazıları şunlardır:

- "Satranç egzersizi özellikle başta masa başına oturup yeri geldiğinde saatlerce sabit kalarak, oturarak sabırlı davranmayı öğretiyor çocuklara. Sabr kazandırnyor, dikkatli olmayı kazandırıyor, planlama yapmayı kazandırıyor, ileriye dönük plan yapma özelliğini kazandırıyor. Zihinsel etkinliklerini artırıyor ve zekâyı açan bir faaliyet olması nedeniyle bunun aynı zamanda soyut düşünme kavraminı çocuklarda geliştirdiğini, özellikle soyut içerikleri olan sözel derslerde olsun sayısal derslerin soyut bölgelerinde olsun faydası ve katkısı olduğunu düşünüyorum çocuklara. Okula bağhllı̆̆ konusunda da öğrenciler dersinden sonra bu kursa bilerek ve isteyerek katılıyorsa okula bağlllıklarını da arttırdığını düşünüyorum." (Ö9)

- "Bu etkinlikler sosyalleşmelerini sağlıyor. İleride bu katıldığı branşlara yönelik bir meslek algısı oluşuyor. Örnek olarak kendimi gösterebilirim. Girişimcilikduygularını, başarma duygusunu geliştiriyor. Arkadaşlarına karşı sayg̨ gösterme yani kaybetmeyi hazmetme, kabullenme, kazanan takdir etme, kazandığı zaman sevinme. Kısacası karşılaştığı güçlüklerle baş edebilme duygusunu geliştiriyor." (Ö12)

- “Şimdi öğrencilerimize her yönden olumlu katkısı var diyebilirim... Ilk olarak fiziksel, zihinsel, psikolojik ve sosyal. Fiziksel olarak kemik kas yapısını güçlendirir, dolaşım sistemini düzenler, boşaltım sistemini düzenler, her türlü organ yapısın güçlendirir. Dayanıklılık oranını artırır. Sosyal yapıda öğrencinin bir şeyler başarabildiğini, toplumda beğenildiğini, belirli bir şeyleri en azından üstlenebildiğini. Psikolojik yapıda baskı altında hareket edebildiğini (Bunun üstünü kalın harflerle çiziyorum). Çünkü birçok spor dalı psikolojik bir oyundur. Yani siz 2424 olan bir voleybol maçında belirli bir sorumluluğu, o baskıyı kaldıracak öğrenciyi, her öğrenci yani o baskıyı kaldıramaz. Belirli baskıyı kaldıracak ve zamanla o baskıyı kendi iç olarak oturtabilecek öğrenci potansiyelini bu tür sosyal etkinliklerde kazandirtrı." (Ö3)

- "Çocuklar bir işi başarabilmenin mutluluğunu aldıklarnnda yani yatak yarası ki yatak yarası hoş bir görüntü değildir, koku olarak da görsel olarak da, yani hiçbir insan algısına hoş görünmez. Çocuk bununla karşılaştığında o ilk şoku bir yaşıyor. Sonrasında öğrendiklerini kullanabildiğini, kullanabileceğini fark ettiğinde meslek derslerine dikkati daha da arttı. Yani aman bunu niye yapryoruz, normalde vakayı görmeden önce çocuk işi şakayla karışık ele alırken gerek sözlü ifadelerde gerekse yazılı ifadelerde işi alaya alır gibi anlatırken, projeye katıldıktan 
sonra daha ciddi daha gerçekçi bir anlatıma yöneldi. İlgisi arttı. Okula bağglliğg konusunda biz hastane evde bakım hizmetleri ekibiyle birlikte koordineli çalışıyoruz... Çocuk onlarla, okuduğu okulun kendisine bir meslek kazandırabileceğinin bilincine vardl." (Ö6)

- "Yani diyor işte, çok sessizdi, bu şekilde kendini buldu, kendini ifade etti. Mesela bizim 11/C sinıfimız var. Geçen sene biz Çanakkale program hazırladık onlarla. Ve öğrenciler orda kendilerini buldular. Kesinlikle sahnede coştular. Yani derste dediler biz bu coşkuyu yakalayamadık bu öğrencilerle Biyoloji öğretmenimiz söyledi. Sen bu sahnede nasll bu kadar performans yakalayabildin dedi." (Ö2)

- "Bu etkinlik sayesinde mesleki derslere olan ilgileri daha fazla arttı....Ayrica teoride öğrendiği bilgilerin uygulamada karşıllğın görünce motivasyonları da artıyor. Aslında bu akademik başarıya da yansıyor. Okuma alışkanlığı kazanıyorlar... Bu etkinlik sayesinde okul kültürün aidiyetleri gelişiyor. Devamsizlık durumlarında ciddi anlamda bir azalma gördüm." (Ö4)

- "Takım çalışması, yardımlaşma, sosyalleşme, iletişim, diyalog kurma, toplumda kendini ifade edebilme, her ne kadar bir spor müsabakası olsa bile kendine öz güven, karar verme, zor durumlarda kazanma kaybetme konumuna geldiğ i zaman ne yapması gerektiği konusunda burada bence çok onlarm kişiliklerinin gelişmesine de faydah olduğuna inanıyorum. Olumsuz katkı konusunda derslerden kaytarma konusunu kullanan çocuklar oluyor. Dersten kaçmak için takıma katılmak isteyenler." (Ö8)

- "Mesela e-okulda katıldığı kısma ne yaptığı hiç açıklanmıyor. O da açıklanmalı bence. Üstün başarll olduğu açıklanmalı. Mesela öyle öğrencileri bakanlık tespit edip daha iyi bir eğitim alabilecekleri bir ortam oluşturulabilir, yardım verilebilir. Mesela resim adına malzeme yardımı. Şövalye yardımı gibi. Teşvik edilmeli. Bu şekliyle yeterli görmüyorum." (Ö11)

\section{Sonuç, Tartışma ve Öneriler}

Araştırmanın sonuçları, alt problemlere göre boyutlandırılarak sunulmuş ve ilgili alanyazına dayalı olarak tartışılmıştır.

Araştırmanın birinci boyutu okullarda yapılan program dışı etkinliklerin türünün belirlenmesine yöneliktir. Okullarda oldukça sinırlı sayı ve türde etkinliğin yapıldığı, en fazla yapılan okulda bile etkinlik türünün 10'u geçmediği, bir okulda ise yalnızca bir etkinliğin olduğu belirlenmiştir. Program dışı 
etkinliklerden beklenen olası yararlar dikkate alındığında, okullarda bu yararları sağlayacak ölçüde etkinlik yapılmadığı ve bu tür etkinlikleri gerçekleştirmeye dönük yeterli çabanın gösterilmediği ya da önem verilmediği söylenebilir. Etkinlik tür ve sayısının azlığı okullardaki eğitim anlayışının bütüncül bir yaklaşıma dayanmadığı, daha çok resmi programı temele alan bir eğitim sürecinin işe koşulduğunu göstermektedir. Mahoney ve Cairns (1997) program dışı etkinlik seçeneklerinin çok olduğu durumlarda, öğrencilerin bireysel ilgi ve gereksinimlerine daha çok hitap edildiği ve bunun sonucu olarak program dışı etkinliklere yönelimin yüksek olduğunu belirtmektedir. Reeves (2008) lise öğrencileri ile yaptığı araştırma da program dışı etkinliklerin akademik başarı üzerinde etkisinin öğrencilerin katıldığı etkinlik sayısı ile değil, türleriyle ilişkili olduğu sonucuna ulaşmıştır. Bu çalışmada sportif etkinliklerin tüm okullar için ortak olan program dişı etkinlik türü olduğu görülmektedir. Yapılan bazı araştırmalarda da (Ekici vd., 2009 ve Karaküçük, 1999) benzer sonuca ulaşıldığı, okullarda uygulanan ders dışı etkinliklerin en fazla sportif faaliyetlerde olduğu görülmüştür. Karaküçük'ün (1999) araştırması okul yöneticilerinin, program dişı etkinliklerde en fazla beden eğitimi öğretmenlerinden yararlanmak istediklerini ve bu etkinliklere yönlendirmenin de bu öğretmenler tarafından öncelikle yapılması gerektiğini düşündüklerini belirtmiştir. Lemmon (2019) da görsel sanatlar ve sahne sanatları etkinliklerinin çocuklara daha çok firsatlar sunmasına karşın, spor etkinliklerin çocuklar tarafından daha çok tercih edildiğini belirtmektedir. Okul ortamında hem çeşitlilik hem sayıca fazla program dışı etkinliğin olması öğrencilerin yönelimlerinde zenginliğe yol açarken daha üst düzey kazanımları da beraberinde getirmektedir. Anadolu Lisesi ve İmam-Hatip Lisesi TÜBİTAK bilim fuarı için proje başvurusu yaptıklarını fakat kabul edilmediği için bu etkinlik alanını okullarında gerçekleştiremediklerini belirtmişlerdir. Bu anlamda bilimsel projeler için okullarda bir çabanın olduğu söylenebilir.

Araştırmada program dışı etkinliklerin okullarda daha çok sözel derslere ilişkin branşlar ve beden eğitimi branşındaki öğretmenlerce yapılmış olduğu belirlenmiştir. Okullarda bir üst öğrenim kurumuna hazırlayıcı sınavlara hazırlık hem okul yönetimleri hem de öğrenciler ve velileri tarafından önemli görülen bir konudur. Bu sinavlara atfedilen önem matematik ve fen bilimleri alanlarındaki derslere ve onları destekleyici etkinliklere olan yönelimi artırmaktadır. Bu çalışmada Fen Lisesinde daha az program dışı etkinlik olması hem öğrencilerin bu tür etkinliklere yöneliminin düşük olması hem de bu 
branşlardaki öğretmenlerden daha çok sınavlara yönelik etkinlik talebinin yüksek olmasıyla ilişkilendirilebilir. Örneğin, okul yönetimlerinin bu branşlardaki öğretmenleri Destekleme ve Yetiştirme Kurslarına yönelik talebi karşılamaya yöneltmeleri, onların program dışı etkinliklerden kaçınmalarına neden olabilir. Bu kurslar nedeniyle ders dışı zamanın azalması da program dışı etkinliklerden kaçınmaya yol açabilir. Ayrıca, bu tür kurslara ücret ödenmesi, program dışı etkinliklere ödenmemesi diğer öğretmenlerin de isteksiz davranmasina neden olabilir.

Araştırmanın ikinci boyutu öğretmenlerin program dışı etkinlikleri nasıl değerlendirdiklerini belirlemeye yöneliktir. Araştırmaya katılan öğretmenler program dışı etkinliklerin "öğrenci", "öğretmen", "okul", "toplum" ve "program" olmak üzere beş kategoride ele alınabilecek olumlu yararlarının olabileceğini değerlendirmektedirler. Bulgular kısmında ayrıntılı olarak yer alan program dışı etkinliklerin yararlarına öğrencilerin özgüven gelişimi, sosyalleşme, sorumluluk duygusu oluşumu, olumsuz davranışlar engelleme, yeni öğrenmeler sağlama, fiziksel gelişimlerine katkı sunma, kendilerini yetiştirme ve geliştirme, öğretmelerin öğrencilerini tanıma firsatı bulması, okul ikliminin olumlu etkilenmesi örnek olarak verilebilir. İlgili araştırma sonuçları çoğunlukla bu sonuçları destekler nitelikteyken (Ekici vd., 2009; Gömleksiz ve Kılınç, 2015; Görkem, 2012; Malkoç ve Kaya, 2015; Karaküçük, 1999), Sarı (2012)'nın çalışması program dışı etkinliklerin öğrencilerin gelişimine katkısının olmadığı yönündedir. Ayrıca, bu tür etkinliklerle öğretmenler öğrencilerini her yönüyle tanıma fırsatı bulduklarını, öğrenciyle olan iletişimlerini güçlendirdiğini ve okul iklimine de olumlu katkı sunmasından dolayı yapılmasını önemsediklerini belirtmişlerdir. Niteliği yüksek, iyi yapılandırılmış program dışı etkinlilerin öğrenciler ile bu tür etkinliklere rehberlik eden öğretmenler arasındaki etkileşimi güçlendirdiğini göstermektedir (Holloway, 2002). Haensly vd. (1985), çocukların yetişkinlerle etkileşimi, yetişkin davranışları edinmeleri, kişilik gelişimlerine yardımcı olacağını belirtmektedir. Böyle bir etkileşimde öğretmenin iletişime açık, yenilikçi rehberlik becerilerinin yüksek olması öğrenci ile öğretmen arası iletişimi güçlendirecektir. Hill (2010), öğretmenlerin rol model olarak iletişim içinde olmalarının ve aynı yaş grubu akranların program dışı etkinliklere katılarak edindikleri deneyimlerin oldukça önemli ve değerli olduğunu belirtmektedir. Program dışı etkinliklerden beklenen yararların artırılması için bu tür etkinliklere daha fazla zaman ayrılması, maddi olanakların 
arttırılması, kapsamının genişletilmesi gerektiğine yönelik öğretmenlerin önerileri bulunmaktadır.

Araştırmanın üçüncü boyutu okullarda program dışı etkinliklerin planlanma sürecine ilişkin durumu belirlemeye yöneliktir. Program dışı etkinliklerin çoğunlukla okul yönetimi veya öğrencilerle birlikte planlandığı, yapılan planların okul yönetimi ve ilçe milli eğitim müdürlüğünün onayının alınması şeklinde gerçekleştiği belirlenmiştir. Ayrıca, öğretmenlerin etkinlikleri belirleme sürecinde öğrencilerle veya okul yönetimiyle birlikte karar vermelerinin planlara uyulması ve etkinliklerin devam etmesinde etkili olduğu görülmüştür.

Araştırmanın dördüncü alt boyutu okullarda program dışı etkinliklerin uygulama sürecine ilişkin durumu belirlemeye yöneliktir. Öğrencilerin program dışı etkinliklere kendi ilgi ve gereksinimlerini karşılamaya dönük amaçlarla katılımları ve isteklilik durumları program dışı etkinliklerin uygulanma sürecini kolaylaştırdığı bu boyuttaki sonuçlardan birisidir. Araştırmada öğrencilerin yeteneklerinin ve becerilerinin seçilen etkinlikle ilişkili olması, ilgili ve istekli olmaları, etkinlikte kendilerini rahat hissetmeleri, kendini keşfetme, çevresine kendini gösterme, sosyalleşme, olumsuz imajlarını düzeltme, özgüven kazanma gibi amaçlarla etkinliklere katıldıkları sonucuna ulaşılmıştır. Holloway (2002) program dışı etkinliklere öğrenci katılımının öğrenen üzerindeki olumlu etkilerini aynı zamanda öğrencilerin bu etkinliklere daha yüksek düzeylerde katılımının gerekçesi olarak vurgulamaktadır. Aybek vd. (2011)'nin çalışması öğrencileri ders dışı etkinliklere en çok yönlendiren etkenin çevre olduğunu belirlemiştir. Ekici vd. (2009) ve Karaküçük (1999) araştırmalarında öğrencilerin bu etkinliklere katılma nedenlerinin en çok okulda dikkat çekme olduğu sunucuna ulaşmışlardır. Çevresine kendini gösterme ve toplumda bir yer edinme amaciyla etkinliklere katılan öğrencilerin olması, çevre faktörü anlamında araştırma sonucunu desteklemektedir. Araştırma sonucunda öğrencilerin etkinliği önemsemesi, kendilerinin istemesi, etkinliğe devam konusunda özen göstermesi, etkinliği öğretmenlerle beraber planlaması, etkinliğe katılımda ısrarcı olması, etkinliğin öğrenciyi tatmin etmesi gibi nedenler uygulamadaki isteklilikleri olarak karşımıza çıkmaktadır. Program dışı etkinliklerin uygulama sürecini kolaylaştıran bu tür olumlu durumlar yanında, bazı fiziki altyapı yetersizlikleri, araç-gereç, materyal eksikliği, çevresel destek eksikliği gibi yetersizliklerin uygulama sürecini zorlaştırdığı belirlenmiştir. Okulların sportif ve sanatsal etkinliklerde yeterli fiziki 
alan ve donanımlara sahip olmamaları, taşımalı olarak gelen öğrencilerin olması, zaman noktasındaki sinırlılıklar, okulların ders yükünün fazla olması (günlük ders saati), bazı velilerin süreç başında program dışı etkinliklere şüpheli davranması, materyal eksikliği, veli ve toplumun bu tür etkinliklere olumsuz bakış açısı, ailelere maddi külfet getirmesi bu zorluklara örnek olarak verilebilir. Karşılaşılan zorluklarlarla ilgili yapılan bazı araştırmalar da (Arı, 2010; Erkoç, 2019; Gömleksiz ve Kılınç, 2015; Karakuş vd., 2012; Karakaş-Özür ve Şahin, 2017; Karaküçük, 1999; Malkoç ve Kaya, 2015; Köse, 2013; Onay ve Gelen, 2013; Sözer, 2015; Tetik, 2008; Vural, 2018; Yiğit, 2008) bu sonucu desteklemektedir. Sarı (2012), ailesi alt gelir düzeyinde olan öğrencilerin ders dışı etkinliklere katılım düzeyinin diğer öğrencilerin katılım düzeyinden düşük olduğu sonucuna ulaşmıştır. Köse (2007) yaptı̆̆ çalışmada ders dışı etkinliklere öğrencilerin katılmama nedenlerini ailenin düşük ekonomik gelire sahip olmasından kaynaklandığı sonucuna varmıştır. Oysaki program dışı etkinlerin işlevleri arasında; düşük sosyo-ekonomik ailelerden gelen çocuklara üst sosyo-ekonomik ailelerin çocuklarının katıldığı etkinliklere (dans, müzik, sanat, spor vb.) katılım fırsatı verme, dolayısıyla, dezavantajlı grupların ilgi ve gereksinimlerine dönük etkinlikler sunulmasını mümkün kılma (Hollaway, 2002) da yer almaktadır. Program dışı etkinliklerin bu işlevini yerine getirmesinde bu araştırmaya katılan öğretmenlerinde vurgulamış olduğu maddi kaynakların artırılması önerisi bu bağlamda önem kazanmaktadir.

Araştırmanın beşinci alt boyutu öğretmenlerin program dışı etkinlikleri yürütürken paydaşlarıyla (öğrenci-okul yönetimi-veli) olan etkileşim sürecinin nasıl işlediğini belirlemeye yöneliktir. Araştırmaya katılan öğretmenlerin paydaşlarıyla etkileşimlerinin olumlu olduğu sonucuna ulaşılmıştır. Öğrencilerin kendilerini yakın hissettikleri, öğrenciyle olumlu iletişim ve duygusal bağ kurdukları, samimi bir ortamda etkinlikleri yürüttükleri sonucu elde edilmiştir. Okul yönetimlerinin etkinlik giderlerini karşılama ve malzeme desteği sağladığı, öğretmenlerin etkinlik sürecinde okul yönetimiyle sürekli iletişim halinde oldukları, okul yönetimlerinin öğretmen ve öğrencilere güvendiği, etkinliklere olumlu baktığı, hatta etkinliklere bizzat katılıp izlediği ve gerekli izinlerin alınmasında yardımc olduğu belirlenmiştir. Okul yönetimlerinin bu olumlu tutumu Karaküçük (1999); Onay ve Gelen'in, (2013) yaptıkları çalışmalar ile örtüşürken, bazı araştırmaların (Arı, 2010; Erkoç, 
2019; Gömleksiz ve Kılınç, 2015; Sözer, 2015; Tetik, 2008; Vural, 2018) sonuçları ile farklılık gösterdiği görülmektedir. Bu farklılık bu araştırmaya dahil edilen okulların yöneticilerinin bunun sonucu olarak akademik konular yanında program dışı etkinlikleri de öğrenci gelişimi açısından önemli görmeleri ile açıklanabilir. Velilerin okullarda düzenlenen program dışı etkinliklerin yürütülmesi sürecine desteğinin genel olarak olumlu olduğu belirlenmiştir. Velilerin öğrencilerin etkinliğe katılmasında izin verme noktasında destek olduğu, bazı velilerin süreç başında isteksizlik gösterebildiği, fakat süreç boyunca veya sonunda bakış açılarının olumlu yönde geliştiği, çoğu velinin ise çocuklarının bu tür etkinliklere katılmasında ısrarcı oldukları sonuçlarına ulaşılmıştır. Araştırmadan elde edilen bu sonuç bazı araştırmaların (Arı, 2010; Erkoç, 2019; Gömleksiz ve Kılınç, 2015; Karaküçük, 1999; Onay ve Gelen, 2013; Sözer, 2015; Vural, 2018) sonuçları ile çelişmektedir. Bunun sebebi velilerin program dışı etkinliklerle çocuklarının kötü davranışlarının önüne geçtiğine inanmaları, streslerini atarak rahatladıklarını düşünmeleri olabilir. Nitekim Milli Eğitim Bakanlığı'nın da bu tür etkinliklere olan olumlu bakış açısı ve politikalarının yöneticiler tarafından da benimsenip yukarıda da vurgulanmış olan destekleyici yaklaşımlarının okul iklimine yansımasının sonucu olarak velilerin eğilimlerini de olumlu etkilemiş olabilir.

Araştırmanın son alt boyutu program dışı etkinliklerin öğrencilere yönelik kazanımlarının belirlenmesidir. Öğretmenler program dışı etkinliklere katılan öğrencilerin okul kültürü, akademik, psikolojik, fiziksel ve sosyal yönlerden gelişimlerine olumlu katkısı olan bazı kazanımlarının olduğunu ve bu katılımlar sonucunda öğrencilerin kendilerini gösterebilecekleri performanslar sergileyebildikleri değerlendirmesine sahiptirler. Bu sonuçlar bazı araştırmanların (Akın, 2012; Çifçi ve Yurdal, 2016; Ergül, 2017; Erkoç, 2019; Karakaş Özür veŞahin, 2017; Malkoç ve Kaya, 2015; Okur Berberoğlu ve Uygun, 2013; Sözer, 2015) sonuçlarıyla benzerlik göstermektedir. Yurtdışında yapılan çalışmalar incelendiğinde; program dişı etkinlilere katılımın akademik başarıyı olumlu yönde etkilediği (Cooper vd.,1999; Fredricks ve Eccles, 2006; Jansen, 2016; Marsh ve Kleitman, 2002; Meadows 2019; Moriana vd., 2006; Reeves, 2008), okulu terk etme oranlarını ve devamsızlıklarını azalttığı, bu öğrencilerin daha az disiplin sorunu yaşadıkları (Hill, 2010), risk altındaki öğrencilere okullarıyla olumlu yönde bağ oluşturma fırsatı sunduğu görülmüş̧ür (Fredricks ve Eccles, 2006; Holoway, 2002; Mahoney ve Cairns, 1997). Lemmon 
(2019), boylamsal araştırmasında sanata dayalı program dışı etkinliklere katılımın topluma hizmet çalışmalarına gönüllülüğü artırdığı sonucuna ulaşmiştır.

Araştırma kapsamındaki öğrencilerin yaş grubu göz önüne alındığında, program dışı etkinliklerin sağladığı katkılarının daha önemli hale geldiği söylenebilir. Burnett, Thompson, Bird ve Blakemore (2011) ergenlik dönemini derin bir sosyo-duygusal gelişme dönemi olarak tanımlayıp, yetişkin rollerini deneme ve önemli yetişkin sorumluluklarını alarak arkadaşlık etme, bilimsel çalışmalara ve ders dışı etkinliklere katılma ve tüketici olarak seçim yapma zamanı (Halpern-Felsher, Millstein ve Irwin, 2002) olarak vurgulamışlardır (Soytük ve Tepeköylü -Öztürk, 2020). Bu anlamda farklı tür ve zenginliklerdeki program dışı etkinliklere katılım, bu yaş dönemi gereksinimlerini karşılamak için firsatlar sunmaktadır.

Ayrıca öğretmenler E-okul sisteminde sosyal etkinliklere katılımın kaydedilmesini olumlu değerlendirmekte ve kapsamının genişletilmesine vurgu yapmaktadırlar. MEB (2018) Eğitim Vizyon belgesinde de bu konuya vurgu yapılmaktadır. Bir eğitim raporunda (TEDMEM, 2019) ise öğrencilerin bu tür etkinliklere katılımlarının e-okula sadece kayıt edilmesinin o öğrencinin doğrudan o alanda gelişim gösterdiğinin bir kanıtı olamayacağını, bu yüzden öğrencilerin okul içinde gerçekleştirdikleri sosyal etkinliklerinin izlenmesi ve değerlendirilmesinde daha ayrıntılı araçların kullanılması ve bu değerlendirmelerin öğrencilere özel hazırlanan portfolyolarda biriktirilmesi gerektiği şeklinde değerlendirilmektedir.

Araştırma sonuçları genel olarak değerlendirildiğinde; okullarda gerçekleştirilen program dışı etkinliklerin türünün oldukça sınırlı olduğu, bu etkinliklere katılım yüksek olsa bile, bu sınırlılık nedeniyle öğrencilerin ilgi ve gereksinimlerinin yeterince karşılanamayacağı söylenebilir. Öğretmenlerin, bazı zorluklarla karşılaşıyor olsalar bile, program dışı etkinliklere önem atfettikleri, etkinlikleri planlanan şekilde sürdürmeye çaba gösterdikleri, okul yönetimlerinin bu etkinlikleri mali ve yönetsel bakımdan desteklediği, bu etkinliklere katılan öğrencilerin birçok bakımdan çeşitli kazanımlar sağladıkları görülmüştür. Ayrıca velilerin de bu etkinlikleri çoğunlukla destekliyor olması önemlidir.

Araştırma sonuçlarına dayalı olarak şu önerilerde bulunulabilir: (1) Okullarda program dışı etkinlikler sayı ve tür olarak artırılarak daha çok sayıda 
ilgi ve gereksinime hitap edecek şekilde düzenlenmelidir; (2) Milli Eğitim Bakanlığı Sosyal Etkinlikler Yönetmeliği program dışı etkinlikleri eğitim sürecinin temel bileşenlerinden birisi olarak görmektedir. Bu nedenle okullar çok daha fazla sayı ve türde program dışı etkinliği gerçekleştirebilecek fiziki alt yapı ve destekleyici olanaklara kavuşturulmalı ve program dışı etkinlik yürüten öğretmenlere özendirici düzeyde ücret ödenmelidir. Ayrıca okullara yapılan kaynak tahsislerinde bu tür etkinlikleri nitelikli düzeyde gerçekleştirebilecek mali kaynak tahsis edilmelidir; (3) Öğretmenlere yönelik hizmetiçi eğitim programlarına program dışı etkinlikler konusu da eklenmeli, ayrıca öğretmen eğitimi programlarında yer alan seçmeli Program Dışı Etkinlikler dersi kuramsal ve uygulamalı bir içerikle zorunlu hale getirilerek öğretmen adaylarının bu tür etkinlikleri hazırlama ve uygulama yetkinliği geliştirilmelidir. 


\title{
EXTENDED ABSTRACT
}

\section{Evaluation of Extracurricular Activities Implemented in High Schools According to Teachers' Opinions

\author{
Ali Kocayiğit - Necla Ekinci \\ Muğla Sttkı Koçman University
}

Experiences acquired through extracurricular activities are an important component of the educational process. Therefore, educators need to consider not only classroom variables but also other variables out of classroom affecting students throughout all day to create a positive learning environment. Currently, learning process in schools is largely based on in-class activities, but many students are also looking for learning activities outside the traditional classroom environment. It is also possible for students to achieve some learning through extracurricular activities that are implemented outside the classroom. Extracurricular activities do not only support, complete or enhance students' school performance, but also some other aspects of them such as personal development, leisure, health, values. PISA results show that students participating extracurricular activities more in the countries (e.g. Finland) where more extracurricular activities are organized have better results. In addition, extracurricular activities provide opportunities for students from lower socio-economic status to participate in activities such as dance, music, arts, sports, as attended by students from upper socio-economic status. Extracurricular activities also allow interaction among students from different peer groups (interest, talent, income, achievement, etc.) and increase their collaboration skills. When the activites are well planned and structured, they help students improve more complex skills like problem solving and coping skills. Additionally, such activities lead to better interaction between students and teachers who guide them.

Although there are some difficulties in the implementation of extra-curricular activities in schools, the research indicate that they are very important in many ways for the students such as contributing to academic achievement, personality development, improving social and individual values, developing sense of responsibility, and creating better school climate and culture. In 
addition to significance of extracurricular activities for the students, some official decisions and practices in the field of education also make extracurricular activities more important. The Turkish Higher Education Council (2018) included an elective course with the name of Extracurricular Activities in teacher education programs. In the 2023 Education Vision Document of the Ministry of National Education (MoNE, 2018), a high emphasis is attached to extra-curricular activities for the versatile development of students and currently participation of students in these activities is proposed to be include in the assessment. Significance of extracurricular activities for student development and current policies emphasizing importance of them have been effective in determining extracurricular activities in high schools as a research topic. In this study, it is aimed to evaluate the extracurricular activities that are required to be implemented in schools by the Regulation of Social Activities for Educational Institutions of MoNE.

In the study, case study design, which is one of the qualitative research models, was implemented. The state of the research is the way in which extracurricular activities are structured. Teacher opinions on the planning and implementation processes of the extracurricular activities constitute the analysis unit. The study group consists of 12 teachers working in different types of high schools in a district in Burdur province. While specifying the study group, maximum diversity and criterion sampling methods were employed. The data of the study were obtained by using a semi-structured interview form prepared by the researchers in the fall semester of 2019-2020 (in December). The participants of the study were selected from among the teachers who conducted the extracurricular activities previously. The data of the study were analyzed through content analysis which is one of the qualitative data analysis techniques. First codes were formed from the data and then the overlapping codes were revised. Sub-themes were formed and findings were presented holistically within pre-determined general thematic framework.

The result of the study indicate that a fairly limited number and type of activities were held in schools, the types of activity do not exceed 10 in none of the schools, even there is only one activity in a school. Considering the potential benefits from extracurricular activities, it can be said that there are not sufficient activities in schools to provide these benefits and that sufficient effort or consideration is not given to carry out such activities. The scarcity of activity types and number suggest that educational practices at school are still 
based on in-classroom activities within the frame of formal curricula, not based on a holistic approach. The teachers attach positive benefits to extracurricular activities under five categories: student, teacher, school, society and curriculum. The benefits of extracurricular activities include the development of self-confidence, socialization, development of sense of responsibility, reducing negative behaviors, providing different learning opportunities, contributing to their physical development and self-development, providing chance to teachers to get to know their students, and improving school climate. It was determined that the extracurricular activities were mostly planned with the school administration or students, and that the plans were implemented following the approval process of the school administration and the district directorate of National Education. In addition, it was found that if teachers make their decisions in collaboration with students or school administration in activity determining process, they comply with the plans and continue the activities regularly. Participation and willingness of students in extracurricular activities for purposes of meeting their own interests and needs facilitate the implementation process of extracurricular activities. School administrators are willing to provide material support for the activities. Teachers have the assessment that students participating in extracurricular activities have some positive contribution to the development of school culture, academic, psychological, physical and social aspects.

When the results of the research are evaluated as a whole, it can be said that the type and number of extracurricular activities carried out in schools are quite limited, and even if the participation in these activities is high, the interests and needs of the students cannot be sufficiently met due to this limitation. It was found that teachers, even if they facie some difficulties, give high importance to extracurricular activities and try to maintain activities as planned. School administrations support these activities financially and executively. Students who participate in these activities make various gains in many ways.

\section{Kaynakça / References}

Akın, F. (2012). Okul içi ve sınıf dışı öğrenmelerin öğrenci başarısına etkisi. Yayınlanmamış Yüksek Lisans Tezi, Mehmet Akif Ersoy Üniversitesi Sosyal Bilimler Enstitüsü, Burdur. 
Arı, Ç. (2010). Müze bilinciöğrenme alanı etkinliklerinin gerçekleşebilirliğine ilişkinöğretmen görüşleri. Yayımlanmamış Yüksek Lisans Tezi. Anadolu Üniversitesi Eğitim Bilimleri Enstitüsü, Eskişehir.

Aybek, A., İmamoğlu, O. ve Taşmektepligil, M. Y. (2011). Öğrencilerin beden eğitimi dersi ve ders dişı etkinliklerine yönelik tutumlarının değerlendirilmesi. Spor ve Performans Araştırmaları Dergisi, 2(2), 51-59.

Apaydinli, K. ve Şentürk, N. (2012). Ders dışı sosyal (müziksel) etkinliklerin genel lise öğrencilerinin kural dışı davranış gösterme eğilimlerine etkileri. International Journal of New Trends in Arts, Sports \& Science Education (IJTASE), 1(1), 67-79.

Bartkus, K. R., Nemelka, B., Nemelka, M. ve Gardner P. (2012). Clarifying the meaning of extracurricular activity: A literature review of definitions. American Journal of Business Education, 5(6), 693-704.

Büyüköztürk, Ş., Kılıç Çakmak, E., Akgün, Ö. E., Karadeniz, Ş. ve Demirel, F. (2018). Bilimsel araştırma yöntemleri (24. Bask1). Ankara: Pegem Akademi.

Cooper, H., Valentine, J. C., Nye, B. ve Lindsay, J. J. (1999). Relationships between five after-school activities and academic achievement. Journal of Educational Psychology, 91(2), 369-378.

Creswell. J. W. (2017). Nitel araştırmacılar için 30 temel beceri. (Çev. Ed. H. Özcan). Ankara: Anı Yayıncilik.

Creswell. J. W. (2018). Nitel araştırma yöntemleri Beş yaklaşıma göre nitel araştırma ve araştırma deseni (4. Baskı) (Çev. Ed. M. Bütün, S. B. Demir).Ankara: Siyasal Kitabevi.

Çengelci, T. (2013). Sosyal Bilgiler öğretmenlerinin sınıf dışı öğrenmeye ilişkin görüşleri. Kuram ve Uygulamada Eğitim Bilimleri, 13(3), 1823-1841.

Çifçi, T., ve Dikmenli, Y. (2016). Coğrafya öğretmenlerinin sınıf dışı coğrafya öğretimine ilişkin görüşleri. Ahi Evran Üniversitesi Kırşehir Ĕ̆gitim Fakültesi Dergisi (KEFAD), 17(1), 363-382.

Demir, Ö. (2019). Eğitimde program dışı etkinlikler. N. Köksal veZ. Ayvaz Tuncel (Ed.), Ĕ̆itimde Program Dışı Etkinlikler içinde(s. 20-38).Ankara: Pegem Akademi.

Dinçer, M. G. (2009). Müzik dersi ve ders dışı müzikal etkinliklerin ilköğretim 7. stnıföğrencilerinin sosyalleşmelerine etkisi.Yayınlanmamış doktora tezi, Selçuk Üniversitesi Sosyal Bilimleri Enstitüsü).

Ekici, S., Bayrakdar, A. ve Uğur, A. O. (2009). Ortaöğretim kurumlarındaki yöneticilerin ve öğrencilerin ders dışı etkinliklere bakış açılarının incelenmesi. Uluslararası Insan Bilimleri Dergisi, 6(1), 430-444.

Ekinci, N. (2019). Temel Kavramlar. N. Köksal ve Z. Ayvaz Tuncel (Ed.), Eğitimde program dışı etkinlikler. Ankara: Pegem Akademi. 
Ergül, O. K. (2017). 12-14 yaş grubu ergenlerde "ders dışı etkinlikler ve egzersiz kapsammda" uygulanan fiziksel aktivite programmnn ilköğretim öğrencilerinin yaşam kalitesi üzerindeki etkileri. Yayınlanmamış doktora tezi. Celal Bayar Üniversitesi Sağlık Bilimleri Enstitüsü, Manisa.

Erkoç, Y. (2019). Ortaokul ve lise kademelerindeki ders dışı müzik etkinliklerinin incelenmesi. Yayınlanmamış yüksek lisans tezi. Gazi Üniversitesi Eğitim Bilimleri Enstitüsü, Ankara.

Fredricks, J. A. ve Eccles, J. S. (2006). Is extracurricular participation associated with beneficial outcomes? Concurrent and longitudinal relations. Developmental psychology, 42(4), 698-713.

Glesne, C. (2015). Nitel araştırmaya giriş (5. Baskı). (Çev. Ed. A. Ersoy, P. Yalçınoğlu). Ankara: Anı Yayınclik.

Gömleksiz, M. N. ve Kılınç, H. H. (2015). Ortaokullarda sosyal kulüp etkinlikleri kapsaminda yapılan toplum hizmeti çalı̧malarına ilişkin öğretmenlerin görüşleri. Turkish Studies - International Periodical for the Languages, Literature and History of Turkish or Turkic, 10 (3), 495-512.

Görkem, D. (2012). İlköğretim öğrencilerinin sosyal etkinliklere katılma durumlarmın akademik başarılarına etkisi. Yayınlanmamış yüksek lisans tezi. Dokuz Eylül Üniversitesi Eğitim Bilimleri Enstitüsü, İzmir.

Güler, A., Hahıcıŏ̆lu, M. B. ve Taşğın, S. (2015). Sosyal bilimlerde nitel araştırma (2. Baskı). Ankara: Seçkin Yayıncllk.

Haensly, P. A., Lupkowski, A. E. ve Edlind, E. P. (1985). The role of extracurricular activities in education. The High School Journal, 69(2), 110-119.

Hill, R. E. (2010). Extracurricular activities: An examination of student achievement in the Lee's Summit school district. Yayınlanmamış yüksek lisans tezi, Baker University.

Haegele, J. A., Aigner, C., ve Healy, S. (2020). Extracurricular activities and bullying among children and adolescents with disabilities. Maternal and child health journal, 24, 310-318

Holloway, J. H. (2002). Extracurricular activities and student motivation. Educational Leadership, 60(1), 80-81.

Jansen, L. (2016). The academic impact of extracurricular activities on middle school students. Doktora Tezi, ProQuest Dissertations \& Theses Global, UMI No. 1862184961).

Karakaş-Özür, N. ve Şahin, S. (2017). Sosyal Bilgiler dersinde sınıf dışı etkinliklerin öğrenci başarısına etkisi. Ahi Evran Üniversitesi Kırşehir Eğitim Fakültesi Dergisi (KEFAD), 18(3), 324-347. 
Karakuş, U., Aksoy, B. ve Gündüz, İ. (2012). Dokuzuncu sınıf Coğrafya derslerinde ders dışı etkinliklerin öğretmen görüşlerine göre değerlendirilmesi. Gazi Üniversitesi Gazi Ĕ̆itim Fakültesi Dergisi, 32(2), 489-513.

Karaküçük, S. (1999). Okul yöneticilerinin ders dışı etkinliklere yaklaşımları. Gazi Beden Eğitimi ve Spor Bilimleri Dergisi, 4(3), 51-62.

Köse, E. (2007). İlköğretim öğrencilerinin ders dışı etkinliklerini tercih etme nedenleri. Atatürk Üniversitesi Bayburt Eğitim Fakültesi Dergisi, 2(3), 46-61.

Köse, E. (2013). Eğitim kurumlarında gerçekleştirilen ders dışı etkinliklerin sınıflandırilmasına yönelik bir öneri. Uluslararası Türkçe Edebiyat Kültür Ĕ̆itim Dergisi, 2(2), 336-353.

Lemmon, L. J. (2019). Benefits of participation in arts-based extracurricular activities for youth. Doktora Tezi, University of Alabama Libraries.

Mahoney, J. L. ve Cairns, R. B. (1997). Do extracurricular activities protect against early school dropout?. Developmental psychology, 33(2), 241.

Malkoç, S. ve Kaya, E. (2015). Sosyal Bilgiler öğretiminde sınıf dışı okul ortamlarının kullanımı. İlköğretim Online, 14(3), 1079-1095.

Marsh, H. W., ve Kleitman, S. (2002). Extracurricular school activities: The good, the bad, and the nonlinear. Educational Review, 72, 464-514.

Milli Eğitim Bakanlığı Eğitim Kurumları Sosyal Etkinlikler Yönetmeliği (Haziran 8, 2017). Resmi Gazete. Sayı: 30090. 21.09.2019 tarihinde https://www.resmigazete.gov.tr/eskiler/2017/06/20170608-5.htm adresinden erişilmiştir.

MEB. (2018). 2023 Eğitim vizyonu. 21.09.2019 tarihinde http://2023vizyonu.meb.gov.tr/doc/2023 EGITIM VIZYONU.pdf adresinden erişilmiştir.

Meadows, A. (2019). The impact of participation in extracurricular activities on elementary school students. Journal of Interdisciplinary Undergraduate Research, 11(1), 2.

Moriana, J. A., Alós, F., Alcalá, R., Pino, M. J., Herruzo, J. ve Ruiz, R. (2006). Extracurricular activities and academic performance in secondary students. Electronic Journal of Research in Educational Psychology, 4(1), 35-46.

Okur-Berberoğlu, E. ve Uygun, S. (2013). Sınıf dışı eğitimin dünyadaki ve Türkiye'deki gelişiminin incelenmesi. Mersin Üniversitesi Eğitim Fakültesi Dergisi, 9(2), 32-42.

Onay, İ. ve Gelen, İ. (2013). İköğretim okullarındaki eğitsel kulüp uygulamalarınn etkililiğine ilişkin öğretmen ve yönetici görüşlerinin değerlendirilmesi. The Journal of Academic Social Science Studies, 6(4), 615-647.

Patton, M. Q. (2018). Nitel araşttrma ve değerlendirme yöntemleri (2. Baskı). (Çev. Ed. M. Bütün, S. B. Demir). Ankara: Pegem Akademi.

Posner, G. J. (1992). Analyzing the curriculum. McGraw-Hill Humanities Social. 
Reeves, D. B. (2008). The learning leader/the extracurricular advantage. Educational Leadership, 66(1), 86-87.

Sarı, M. (2012). Ortaöğretim öğrencilerinin ders dişı etkinliklere katılımının incelenmesi. Kuramsal Ĕ̆itimbilim Dergisi, 5(1), 72-89.

Seow, P. S. ve Pan, G. (2014). A literature review of the impact of extracurricular activities participation on students' academic performance. Journal of Education for Business, 89(7), 361-366.

Soytürk, M. ve Tepeköylü-Öztürk, Ö. (2020). Ders dışı sporla ilgili oyunların lise öğrencilerinin davranış örüntülerine etkisi. Ĕ̆itim ve Bilim, 45 (202), 327-343

Sönmez, V. ve Alacapınar, F. G. (2011). Örneklendirilmiş bilimsel araştırma yöntemleri. Ankara: Anı Yayınclik.

Sözer, Y. (2015). Sınıf içi öğrenmeleri destekleyen okul dışı aktiföğrenmeler: Bir meta-sentez çalışması. Yayınlanmamış doktora tezi. Dicle Üniversitesi Eğitim Bilimleri Enstitüsü, Diyarbakır.

TEDMEM. (2019). 2018 Ĕ̆itim değerlendirme raporu. 18.09.2019 tarihinde https://tedmem.org/yayin/2018-egitim-degerlendirme-raporu adresinden erişilmiştir.

Tetik, V. (2008). Genel liselerde sosyal etkinliklerin uygulanmasinda okul yöneticilerinin etkililiği. Yayımlanmamış yüksek lisans tezi. Yeditepe Üniversitesi, İstanbul.

Vural, C. (2018). Öğretmen ve yöneticilerin sosyal kulüp çalışmalarına yönelik tutumları. Yayınlanmamış yüksek lisans tezi. İstanbul Sabahattin Zaim Üniversitesi Sosyal Bilimler Enstitüsü, İstanbul.

Yıldırım, A. ve Şimşek, H. (2006). Sosyal bilimlerde nitel araştırma yöntemleri (5. Baskı). Ankara: Seçkin Yayıncılık.

Yiğit, N. (2008). Ortaöğretim kurumlarında uygulanan öğrenci kulüplerinin değerlendirilmesi. Yayımlanmamış yüksek lisans tezi. Anadolu Üniversitesi Eğitim Bilimleri Enstitüsü, Eskişehir.

Yin, R. K. (2017). Durum çalışması araştırması uygulamaları. (Çev. İ. Günbayı). Ankara: Nobel Yayınları.

\section{Kaynakça Bilgisi / Citation Information}

Kocayiğit, A. ve Ekinci, N. (2020). Ortaöğretim okullarında uygulanan program dışı etkinliklerin öğretmen görüşlerine göre değerlendirilmesi OPUS-Uluslararası Toplum Araştırmaları Dergisi, 16(29), 1810-1838. DOI: 10.26466/opus.749109 